\title{
Basin Framework and Basement Structuring of Lower Benue Trough, West Africa based on Regional Magnetic Field Data: Tectonic and Hydrocarbon Implications
}

\author{
Anthony A. Okiwelu ${ }^{1}$, Emmanuel E. Okwueze ${ }^{1}$, Peter O. Akpan ${ }^{1} \&$ Ikechukwu A. Ude ${ }^{1}$ \\ ${ }^{1}$ Geophysics Research Unit, Department of Physics, University of Calabar, Nigeria \\ Correspondence: Anthony A. Okiwelu, Geophysics Research Unit, Department of Physics, University of Calabar, \\ Nigeria. E-mail: okiwelu2000@yahoo.com
}

Received: July 5, 2014 Accepted: July 29, $2014 \quad$ Published Online: August 20, 2014

doi:10.5539/esr.v4n1p1 URL: http://dx.doi.org/10.5539/esr.v4n1p1

\begin{abstract}
Results from magnetic field modelling of the Lower Benue Trough, West Africa revealed thick sedimentation with maximum values in the neigbourhood of $7,000 \mathrm{~m}-10,000 \mathrm{~m}$. This is in contrast to the average value of $5000 \mathrm{~m}$ suggested by earlier studies. The thick sedimentation represent thermal sag which is a regional post-rift subsidence associated with West and Central Africa rift systems. N-S, NNW-SSE and E-W structural fabrics interpreted from the transformed magnetic data bound the trough. The subsurface magnetic models also revealed extended graben structures that form the major depoceters that are segmented by intrarift horsts and average crustal thickness of $22 \mathrm{~km}$. The qualitative interpretation comprising, analytic signal, directional derivatives and wavelength filtering in frequency domain and subsurface magnetic modelling show that the rift architecture/geometry is controlled by high angle faults and some sinistral transtensional movements that are predominant in the Benue rift system. The low mean anisotropic susceptibility ( $\mathrm{kb}=-6.7 \times 10-4 \mathrm{SI})$ correlating with the directional horizontal derivative (dy) of the magnetic field conform with the sinistral movement in the trough indicating that magnetic anomalies align themselves along fractures/faults/shear zones owing to their variations in physical properties. The characteristics/patterns of the magnetic anomaly wavelength and inferred results from earlier studies on geophysical potential field methods, geological investigation and physical parameters (susceptibility and remanence) obtained from the subsurface magnetic modelling are pointers to non-magmatic origin of the Lower Benue Trough. The basement structuring, basin framework and predominance of anisotropic susceptibilities ( $\mathrm{ka}, \mathrm{kb}$ and $\mathrm{kc}$ ) in three orthogonal directions and remanence suggest tectonic setting in the trough due to Early Cretaceous opening of the South Atlantic Ocean and interplate movement in Africa. The grabens, half grabens, faults and deep sedimentation (depocenters) interpreted from the magnetic data are hydrocarbon related structural features.
\end{abstract}

Keywords: basement, derivatives, graben, magnetic, modelling, rift, trough, wavelength, susceptibility

\section{Introduction}

The Benue Trough is one of the most important rift features in Africa and is believed to be formed by the rifting of the central West African basement during the Cretaceous. The trough is subdivided into Lower, Middle and Upper Benue (Figure 1) with its Southern limit towards the northern boundary of Niger Delta and its northern sector include the easterly Yola/Garoua Flank extending across the Cameroon border and the northerly Gongola Flank. Careful re-examination of geophysical evidence makes it quite clear that there are only three interconnected rifts in West Africa; the Lower Benue Rift which extends from the Gulf of Guinea to a triple junction near Chum and the Gongola and Yola Rifts which extend to the north and east, respectively from the Chum triple junction (Figure 2). These three rifts opened during the ealier part of the Mesozoic and were subsequently filled with Cretaceous sediments (Freeth, 1984). The trough is about $700 \mathrm{~km}$ long and $100-150 \mathrm{~km}$ wide. The trough development is attributed to major horizontal movements along a series NE-SW trending fractures accompanied by basement fragmentation, subsidence and rifting during Early Cretaceous opening of the South Atlantic Ocean (Grant, 1971; Akande, Abimbola \& Erdtmamn, 1971). 


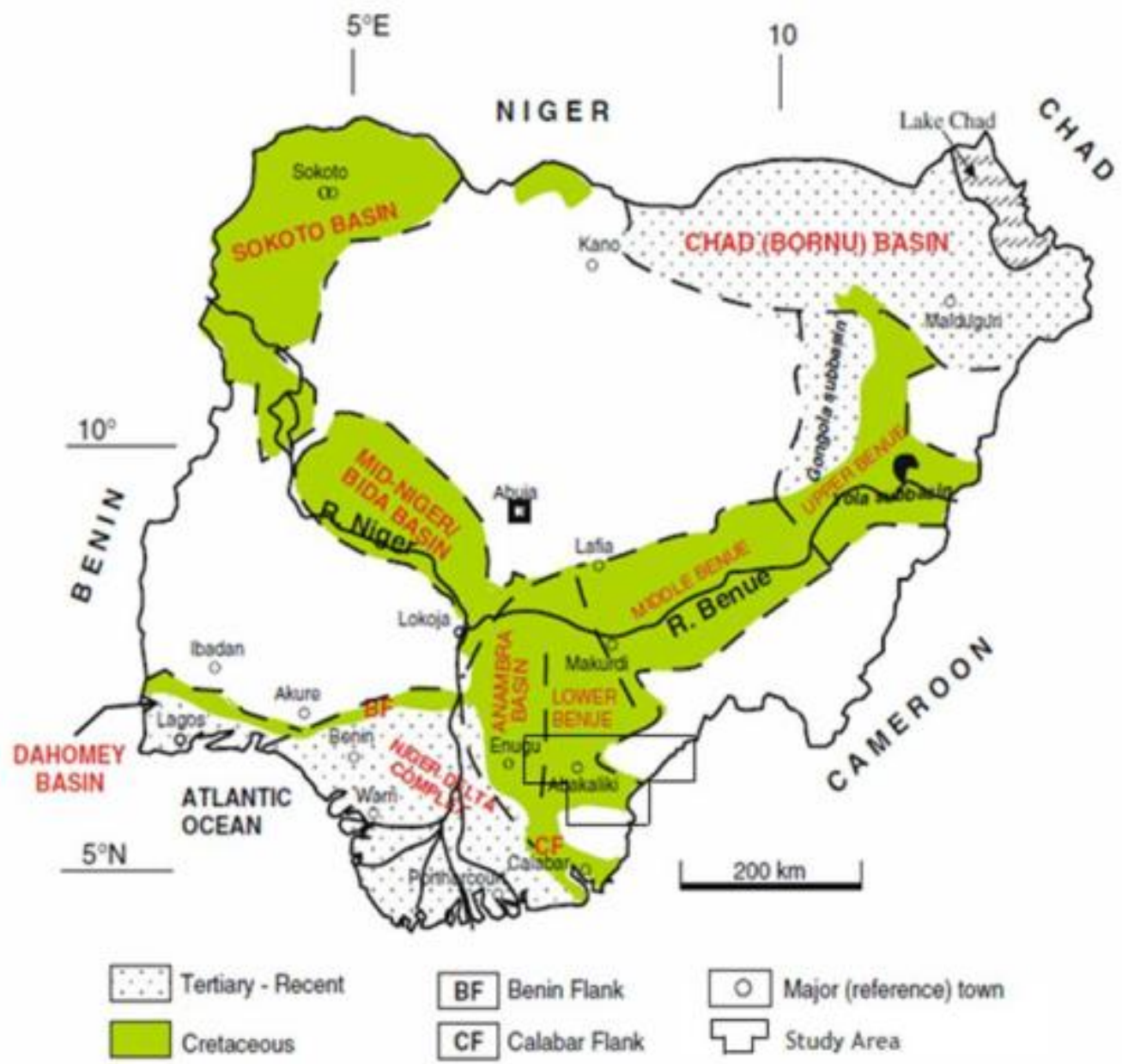

Figure 1. Map of sedimentary basin of Nigeria showing the study area (After, Obaje 2009) 

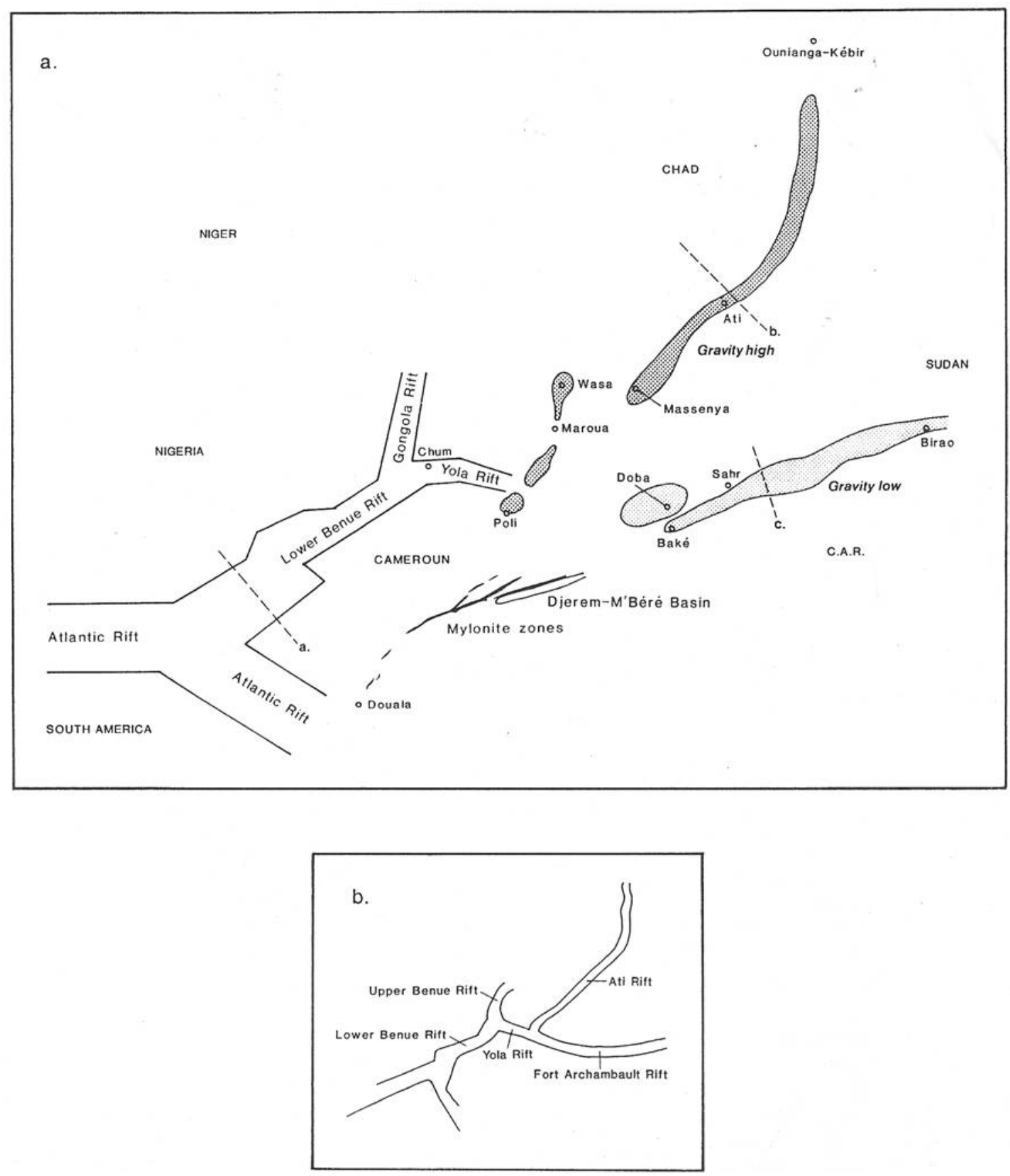

Figure 2. The West African Rift System. (a) The three main West African rifts together with the major Bouguer gravity anomalies mapped by Louis (1970) and used by Burke and Whiteman (1973) as evidence for two further rifts. (b) The five West African rifts suggested by Burke and Whiteman (1973). [After, Freeth, 1984]

Ajakaiye, Hall, Millar, Verheijen, Award and Ojo (1986) using aeromagnetic data delineated a series of long sub-parallel magnetic anomaly belts trending ENE-WSW and suggested that they are probably the signatures of regional structural features representing major tectonic trends. This is due to the fact that they cut across both basement and sedimentary rocks. Depth determination by Ofoegbu and Onuoha (1990) gave ranges in depth to basement between $1200 \mathrm{~m}-2500 \mathrm{~m}$ and they concluded that this part of the Benue Trough may not hold promise in terms of hydrocarbon accumulations. Review of other studies on the Benue Trough using potential field (magnetics and gravity) methods estimated the thickness of the Cretaceous sediments to be in the neighbourhood of 5000m. These include two dimensional models of Cratchley and Jones (1965), Adighije (1981), Ajayi and Ajakaiye (1981) and the three dimensional / two dimensional models of Shemang Jr., Ajayi and Umego (1998). 3-D gravimetric study by Okereke (1990) gave the thickness of the Cretaceous sediment to be above 5000m. 
Recent study on the interpretation of aeromagnetic anomalies over the Lower Benue Trough (Igwesi and Umego, 2013) using spectral analysis technique obtained an average thickness of sediments to be $3.03 \mathrm{~km}$. This study presents data that show deeper sedimentation in the trough and new data sets (anisotropic susceptibilities in three orthogonal direction and remanence) which explain the basement structuring in the trough. Therefore, one of the objectives of this study is to demonstrate a deep sedimentation in Benue Rift and to reveal internal basin geometry. Additional objective is to unravel subtle structural features and their trend within the Lower Benue Rift and their control on sedimentation and subsequent rock deformation. The most important subtle structural features are minor vertical/high angle basement faults and zones of fracturing. These are difficult to detect with seismic data because of the limitations of the seismic method in imaging near vertical structures such as faults and in penetrating high acoustic impedance layers such as sill (Fairhead, 2012) but can be mapped confidently with magnetic imaging. This is because magnetic method responds best to vertical interfaces generating lateral magnetization changes across a bounding fault and separating basement magnetization from sediment magnetization. Where the sedimentary section is considerably thick, the amplitudes of the basement subtle features are attenuated and may be overlooked. Mapping these subtle features in the magnetic data is significant in understanding basin framework of the Lower Benue rift and their control on subsequent deformation. Airborne magnetic data sets are well suited for delineating such subtle structural features, particularly if more than one attribute magnetic maps are used. Magnetic anomalies may reflect tectonic history of a study area, where they align themselves along fractures and faults/ shear zones due to their contrasting physical properties and depths (Elawadi etal., 2013). Thus, we used derivative and filtered maps to achieve our objectives and inferring their tectonic and hydrocarbon implications. Interpreting more than one attribute map is helpful because subtle features are more visible in one data set than in others. In sedimentary basins, basement faults are important structurally because they can influence and hence determine the overall basin architecture, tectonic history and control on mineralization sites, oil and gas traps and groundwater flow pattern (Oyedim, 2009). We therefore, combined 3D magnetic modeling with derivative and filtered data sets to comprehensively deal with the qualitative and quantitative nature of this study. The 3D modelling defined the geometrical features and their physical properties such as anisotropic susceptibilities [ka, $\mathrm{kb}$ and $\mathrm{kc}]$ in three orthogonal directions and remanent magnetization. We quantitavely determined remanent magnetization which is usually overlooked in most studies in magnetometry because it is assumed that images in magnetic anomalies are usually due to induction in the Earth's field.

The Benue Trough is filled with sediments of Cretaceous (Albian-Maastrichtian) age. The sediments are made up of sandstones, shales and limestone and underlain by Precambrian basement (granites and gneisses). The earlier (Albian-Santonian) sediments in the trough are mainly marine in character and their deposition was terminated by the episode of deformation in the Santonian. Following this deformation the marine sediments were eroded and deltaic sediments spread throughout the trough. Continental facies sedimentation persisted until the end of the Cretaceous, apart from short-lived but extensive marine incursion in the Maastrichian (Burke, Dessauvagie \& Whiteman, 1970, Cater, 1963, Fitton, 1980). Petters (1978) documented the main stages of tectonic evolution of the Benue Trough in stratigraphic succession. These include three depositional sequences; an Albian-Cenomanian pyroclastic, paralic shallow marine and fluviatile sequence corresponding to the graben and transitional tectonic stages. The subsequent stages include a Turonian-Conniacian paralic, marine and fluviatile sequence that gave rise to downwarping and resulting widespread marine transgression. The Santonian compressional deformation episode that displaced the depositional axis westward was followed by a Campanian-Maastrichian paralic, marine and fluviatile offlap sequence. The deformation in the Mid-Santonian resulted in the formation of Anambra basin. Post-deformational sedimentation in the Lower Benue Trough, therefore constitutes the Anambra basin. Sedimentation in the Anambra basin thus commenced with the Campanian-Maastrichtian marine and paralic shales of the Enugu Formation and constitutes its lateral equivalents in most places (Obaje, 2009). The stratigraphic succession within the Lower Benue Trough is shown in Figure 3.

Grant (1971) opined that the Benue Trough formed one arm of a Cretaceous RRR triple junction which eventually failed to develop while the other two arms gave rise ultimately to the South Atlantic Ocean. This tectonic model suggests transform fault rather than a ridge. 


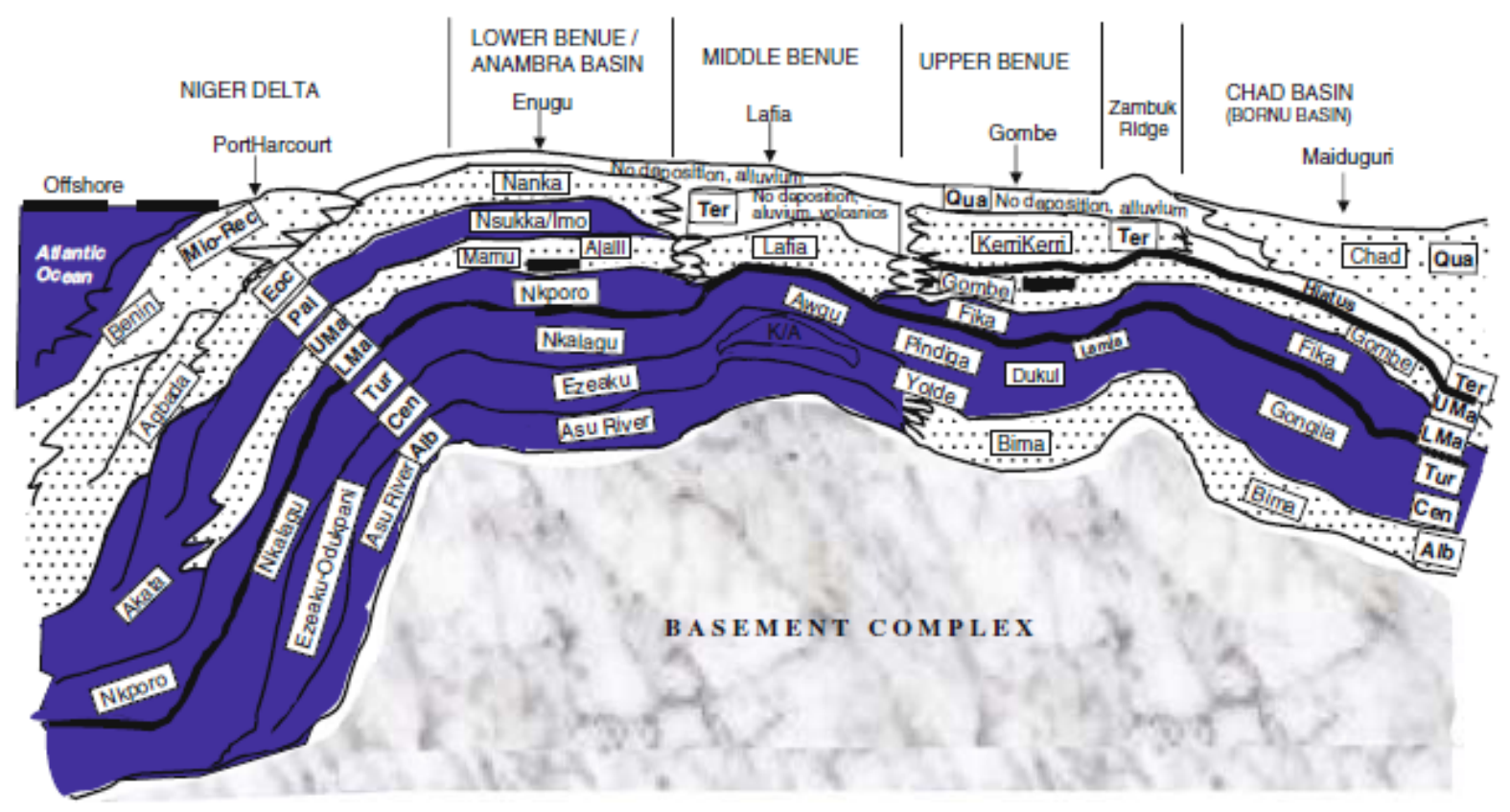

Figure 3. Idealized N-S stratigraphic cross-section across the Chad Basin-Benue Trough - Niger Delta (After Obaje, 2009)

This idea was supported by Benkhelil (1982) who linked the evolution of the Benue rift with major crustal and major sinistral shearing. He stressed that the major structural trends in the basement of the trough are N-S, NE-SW and ESE-WSW and these trends correspond to the general trends of the Cretaceous rifts. This is a pointer that the orientations of the rifts were overwhelmingly controlled by pre-existing structural fabric. This idea that the sinistral movements along the trough axis were influenced by deep seated faults reflecting the continental extention of the transform faults linked with the Proto-Atlantic megashear zone were also supported by Benkhelil and Robineau (1983). Wright (1968) however presented a tensional regime model for the evolution of the Benue Trough. He opined that the tensional forces led to the development of graben systems formed in response to stresses associated with the continental separation of Africa and South America.

Freeth (1984) broke down all gravity profiles across the Lower Benue and Gongola Rifts into two main components; a regional gravity high reflecting thinning at the base of the crust and a superimposed negative anomaly due to the sediment fill in the rift. A positive axial anomaly due to the separation of the continental crust and the consequent intrusion of sheeted dykes was also presented by Freeth (1982).

\section{Materials and Methods}

The airborne magnetic survey over the Lower Benue Trough and part of Anambra basin was part of the nationwide aeromagnetic survey of Nigeria. The survey was completed by Fairey Surveys Limited in 1975 on behalf of Geological Survey of Nigeria. The aeromagnetic data were acquired at a constant flight height of $500 \mathrm{ft}$ $(152 \mathrm{~m})$ above terrain. The flight lines were flown in a $150^{\circ} / 330^{\circ}$ azimuth (NW-SE) at a $2 \mathrm{~km}$ interval, while the tie lines were flown in a $60^{\circ} / 240^{\circ}$ azimuth (NE-SW) at a $20 \mathrm{~km}$ spacing. The corrections for diurnal variation and regional magnetic field removal were previously estimated. The removal of the regional field was based on the International Geomagnetic Reference Field (IGRF) epoch dated 1st January, 1974. This mathematical model is an international agreed global spherical harmonic model of the Earth's core. The airborne magnetic data was supplied by the Geological Survey of Nigeria at a scale of 1: 100,000.

The total intensity data (Figure 4) were gridded using the minimum curvature algorithm by Briggs (1974) with a grid-cell spacing of $1 \mathrm{~km}$. 


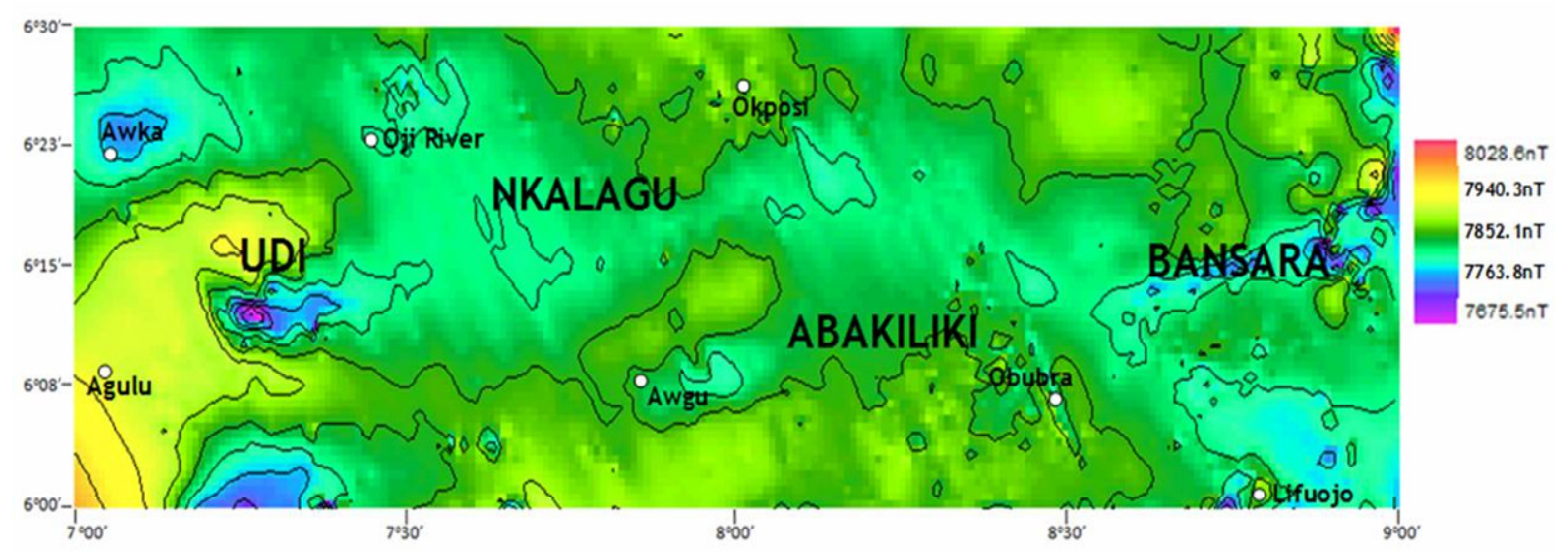

Figure 4. Total magnetic intensity anomaly map of the Lower Benue Tough

To accentuate the internal structure and edges of magnetic sources, residuals and derivatives of the magnetic field were computed. Both first and second degree polynomials were computed to ascertain which of the residuals fields (Figure 5a \& figure 5b) will meet the objective of unraveling deep seated structures and crustal thickness. The residual field (figure 5a) obtained by subtracting from the total intensity data a first order polynomial was found to be more suitable for this study. In this regard, we allowed geology to rule our interpretation. That is, we avoided removing any component of the magnetic field that may be geologically useful in our model. The derivatives computed include analytic signal, first vertical derivative (dz) and directional horizontal derivatives ( $\mathrm{dx}, \mathrm{dy})$. These derivatives gave a clearer image of the edges of major magnetic anomalies and unraveled some subtle trending (lineaments) anomalies that were absent in the total magnetic field intensity map. The magnetic field datasets were also filtered to obtain additional information on the deeper part of the basin and basement structures. The filtered magnetic field data exhibit a ruggered relief with positive and negative anomalies ranging from $-119 \mathrm{nT}$ to $220 \mathrm{nT}$. All this constitute qualitative approach which consists of the separation of magnetic zones or regions of equal behaviour based on the intensity, gradient and the disposition of the contour curves (Olaniyan, Smith \& Morris, 2013). The qualities of the data sets were examined before proceeding to quantitative stage, which involves defining the geometry of the sources and their physical properties (susceptibility and remanence).

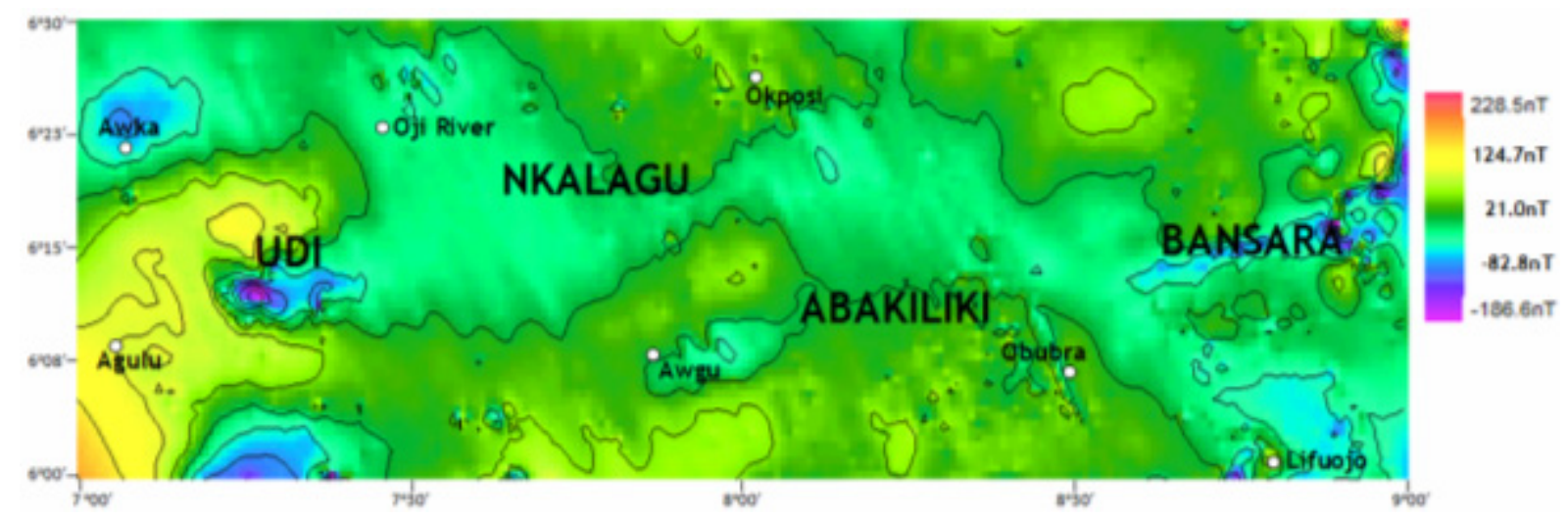

Figure 5a. Residual magnetic field map computed by subtracting the first degree polynomial from the total magnetic intensity values 


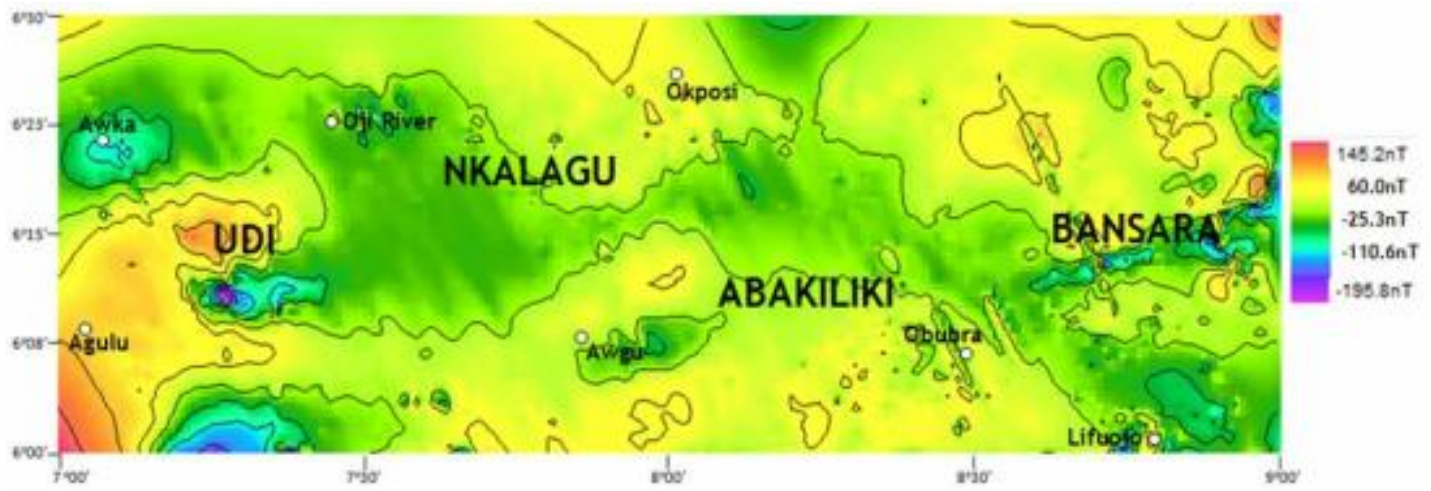

Figure $5 \mathrm{~b}$. Residual magnetic field map computed by subtracting the second degree polynomial from the total magnetic intensity values

The 3D modeling was accomplished using the algorithm of Bhattacharyya (1964) based on the magnetic anomalies of prism-shaped bodies. Based on the geology and tectonics of the Lower Benue Trough interpretational models were erected that established relationship between geophysical, geological and mathematical (geometrical form) models. The suitable geological models amenable to this study are dykes, igneous plugs and sheet-like bodies that are near horizontal (e.g., metamorphic basement blocks). Their geometrical form (mathematical models) equivalents are near-vertical wall-like bodies, vertical pipes and plates respectively. Their geophysical models include line of monopoles, point pole and Sheet of dipoles respectively as shown in Figure 6. Additional geological model that was erected to achieve our objectives is in the form of basement blocks in step-like manner. The equivalent mathematical model is a finite rectangular prism. These models enabled us to define the rift-structure (horst-graben) and thus the basin framework. The dominant magnetic trends in the total magnetic intensity and residual field data are NW-SE oriented magnetic lows crossing the entire basin from Bansara to Abakiliki, Nkalagu, Oji River and Awka. This trend represents the depocenters in the Lower Benue Trough.

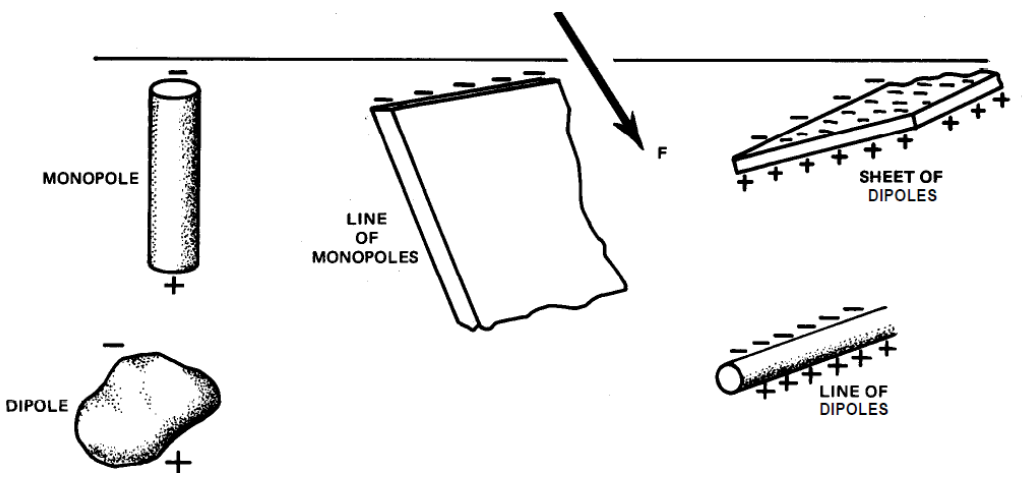

Figure 6. Geophysical models (After Breiner, 1973). Sheet of dipoles, line of monopoles and monopole are applicable in this study

\section{Results}

\subsection{Subsurface Magnetic Models}

Modelled cross-sections (Figures 8- 13) from the residual magnetic field show that the anomalies are both due to structural and lithological variations and there is a variation in extent and thickness of the depocenters between the profiles. In this study anomalies with amplitude of tens of nanoTesla are related to basement structures while magnetic anomalies with amplitude on the order of hundreds of nanoTesla are related to lithological changes in basement or igneous rocks within the sedimentary section. Lithologic variations in magnetic basement or the presence of igneous rocks within the sedimentary section generally produce anomalies with the highest amplitudes (Bird, 1997). Modelled cross-section (line 23) [Figure 8] displays both structural and lithological variations. The geobodies (15 and 16) are igneous bodies within the sedimentary section. The granitc intrusive with susceptibility of $0.004 \mathrm{SI}$ and remanent intensity of $-0.10 \mathrm{~A} / \mathrm{m}$ is $500 \mathrm{~m}$ below the surface. This produced the magnetic low with amplitude of 80nT. The magnetic low in the left flank of the magnetic signature has amplitude of less than 40nT. This low amplitude anomaly is due to the high angle (vertical) fault due to the tilting of fault-bounded block (geobody 18) which is in juxtaposition with the basement block (geobody 21) 
producing a throw of $2000 \mathrm{~m}$. The depression is a tilted fault block that formed on the flank of basement ridge during subsidence of the basin. This structural configuration is interpreted as a half-graben named Bansara graben with sedimentary fill of $6000 \mathrm{~m}$. The value of the mean magnetic susceptibility over the entire profile is $6.2 \times 10^{-3} \mathrm{SI}$. The anisotropic susceptibility $[\mathrm{ka}=0.00800 \mathrm{SI}, \mathrm{kb}=0.02500 \mathrm{SI}, \mathrm{kc}=-0.02300 \mathrm{SI}]$ and remanence are due to deformational processes and metamorphism which changed the stress field in the trough. The maximum thickness of the crust along the profile is $22 \mathrm{~km}$. Results from modelled cross-section (line 36) [Figure 9] show lithological variations within the basement with amplitude of $110 \mathrm{nT}$ related to the magnetic low to the left of the magnetic signature. The low amplitude variation to the right may be due to the infilling of the lithological contact with non-magnetic materials or oxidation of magnetite at fracture plane. The magnetic susceptibility values in $\mathrm{kb}$ direction are all zero. Modelled cross-section (line 12) [Figure10] is purely due to structural variation with amplitude of 56nT. This negative magnetic anomaly is centered over an igneous plug 500m below the surface and is associated with anisotropic susceptibility in three orthogonal directions (ka=0.012SI, $\mathrm{kb}=0.007 \mathrm{SI}$ and $\mathrm{kc}=0.007 \mathrm{SI}$ ). The width of this intrusive (granitic) body is $4300 \mathrm{~m}$ intruding into a basement block (2) $[\mathrm{ka}=0.015 \mathrm{SI}, \mathrm{kb}=-0.007 \mathrm{SI}, \mathrm{kc}=0.012 \mathrm{SI}]$ of width $13000 \mathrm{~m}$. Juxtaposed with this basement block is a structurally lower faulted block (4) creating anisotropic susceptibilities $(\mathrm{ka}=0.016 \mathrm{SI}, \mathrm{kb}=0.005 \mathrm{SI}, \mathrm{kc}=0.0 \mathrm{SI})$. The crust is $20 \mathrm{~km}$ thick from this model. This value of the crustal thickness is compatible to the gravimetric result from simple modeling over the Lower Benue Trough by Fairhead \& Okereke (1987).

Modelled cross-section (profile line 2300) [Figure 11] is characterized by broad magnetic low of wavelength $40 \mathrm{~km}$. Superimposed on the broad negative magnetic anomaly are local positive anomalies (8km wide) and local magnetic low (10km wide) which vary with regard to their amplitudes. These smaller positive anomalies and magnetic low are pointers to the spatial variability of the rift basin fill. The associated geological bodies exhibited anisotropic susceptibilities with remanent intensity ranging from $-0.2000 \mathrm{~A} / \mathrm{m}$ to $-0.1000 \mathrm{~A} / \mathrm{m}$.

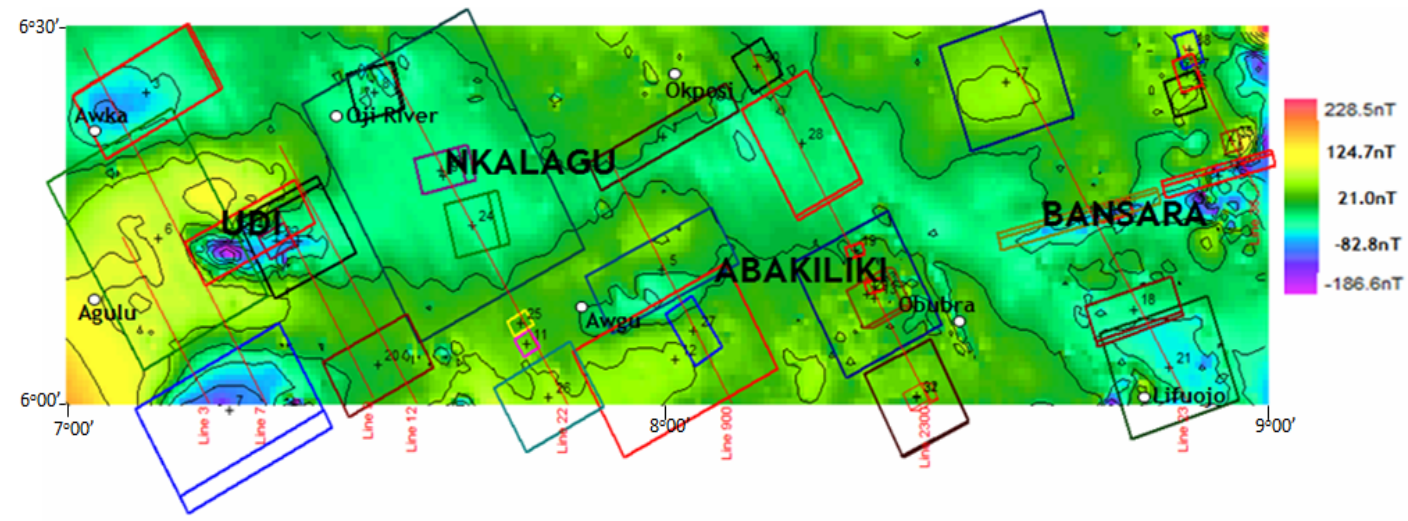

Figure 7. Locations of modelled cross-sections in the residual magnetic field map

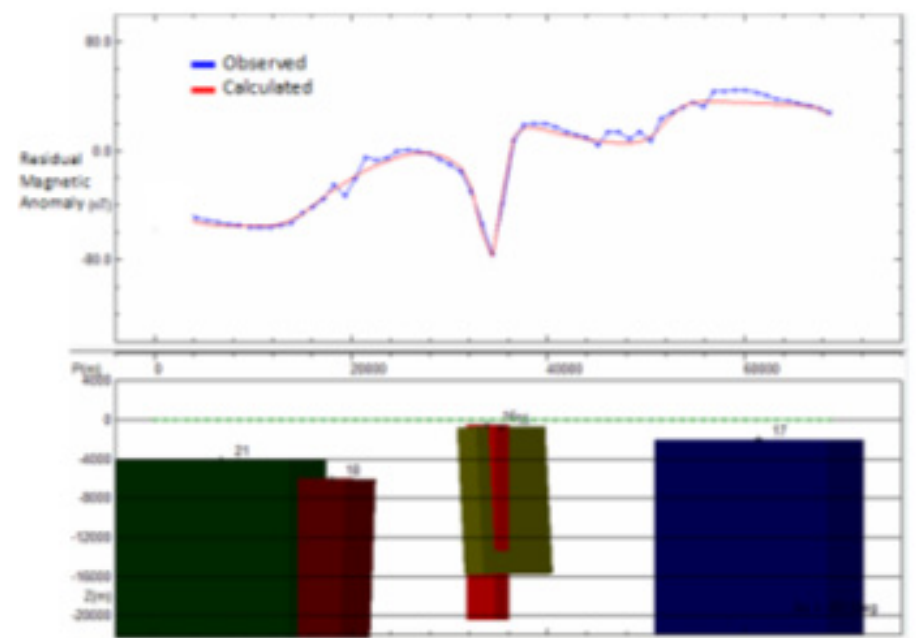

Figure 8. Subsurface magnetic model and profile line 23 across Bansara showing high angle/ vertical fault with throw of $2000 \mathrm{~m}$ and a negative magnetic anomaly of amplitude, $80 \mathrm{nT}$. The negative anomaly is due to an intrusive of magnetic susceptibility (0.004SI) and remanent intensity of $-0.10 \mathrm{~A} / \mathrm{m}$ 


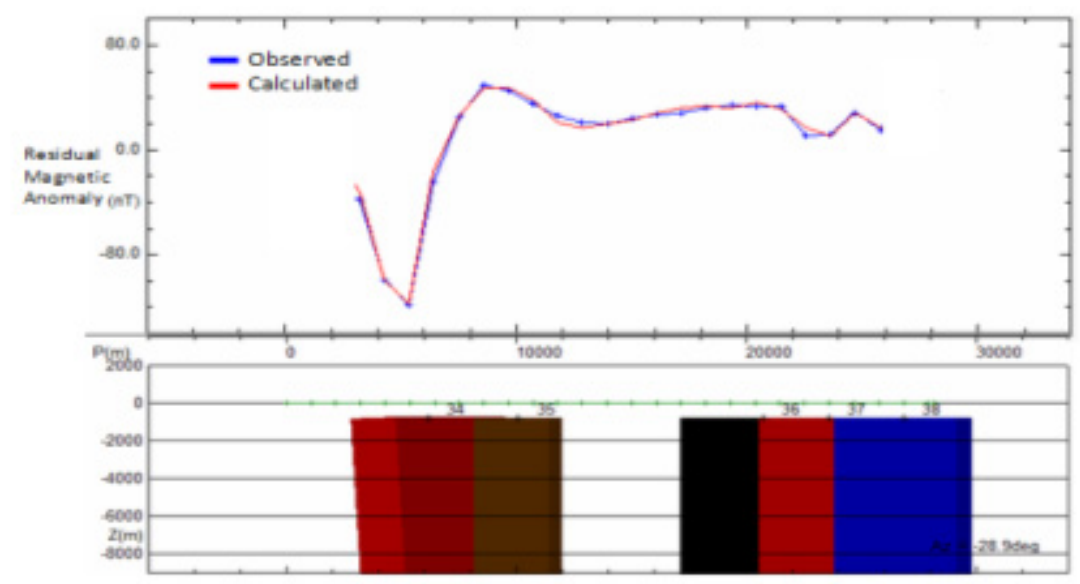

Figure 9. Modelled cross-section (profile line 36) showing anomaly due to lithological changes and thin sedimentary section, $0.8 \mathrm{~km}$ thick

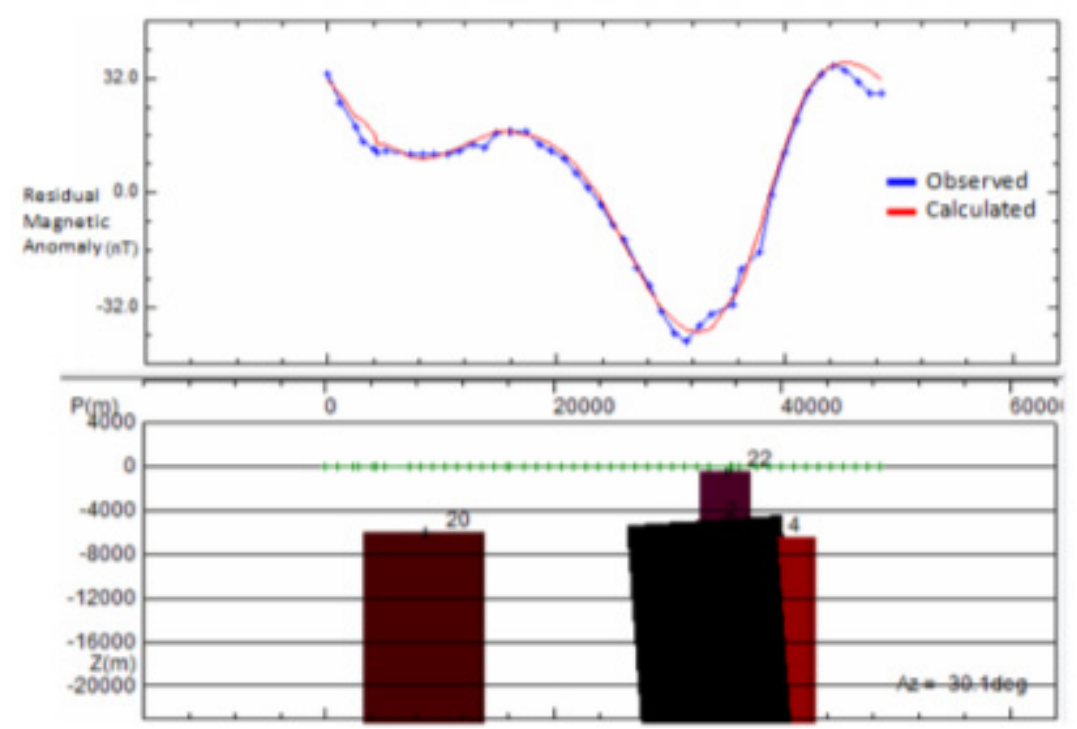

Figure 10. Modelled cross-section (profile line 12) showing negative magnetic anomaly due to intrusive source of low magnetic susceptibility

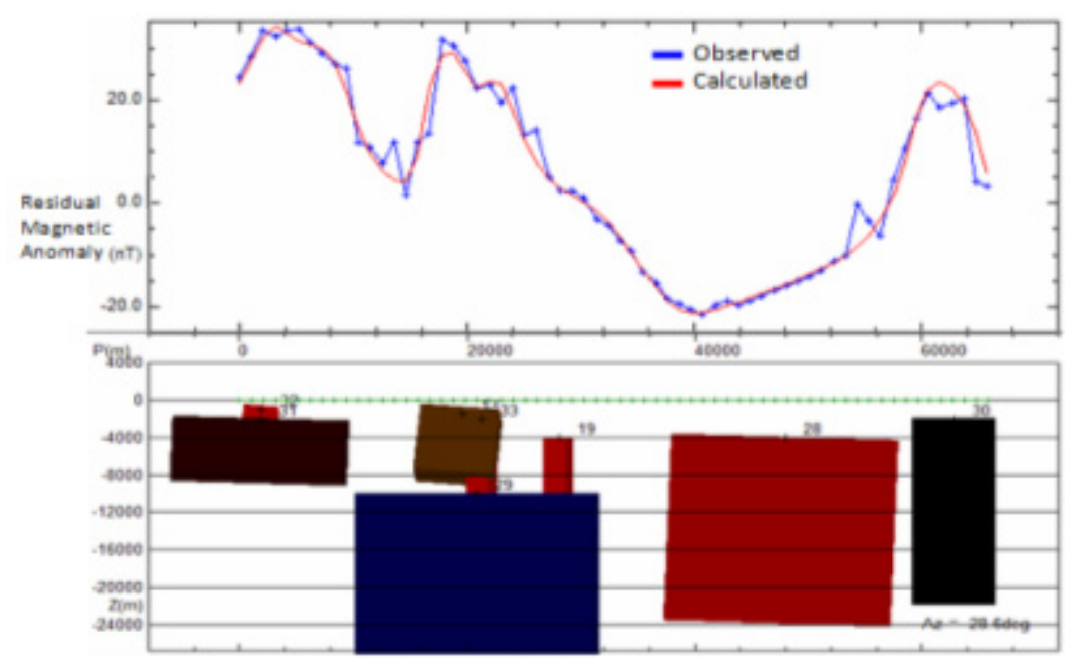

Figure 11. Subsurface magnetic model computed from profile line 2300 across the Abakiliki Anticlinorium of the Benue Tough. The basement arches correspond to the positive magnetic anomalies 
This structural variation of maximum amplitude 50nT is interpreted to represent the rift segment (Abakiliki Trough) in the Lower Benue Trough with maximum sedimentary fill of $4000 \mathrm{~m}$. The positive anomalies are interpreted as intrusion of sources into the shallow crust which represent the basement arches of the Abakiliki anticlinorium. The arching is due to thermal event that originated from heating and expansion of the crust beneath the tectonically thinned basement of the rift system. The high geothermal gradient recorded in the basin (30 F/100ft) attest to this inference. This promoted the Cretaceous source rock into the gas phase (Thomas, 1996). Within the rift segment the crust thinned from $26 \mathrm{~km}$ in the south to $22 \mathrm{~km}$ to the north.

Modelled cross-section (profile line 7) [Figure 12] shows a typical graben structure flanked by basement horsts, filled with Cretaceous sediment of minimum thickness of $4300 \mathrm{~m}$ and maximum thickness of $6700 \mathrm{~m}$ in its central portion. The horst structures and footwall blocks are graben structure of Anambra basin. The entire basement blocks exhibited magnetic anisotropic susceptibilities with mean magnetic susceptibility over the entire profile as $3.4 \times 10-3$ SI. The amplitude of the magnetic high is $150 \mathrm{nT}$. This is a high amplitude anomaly and most high amplitude anomalies indicate large contrast in susceptibilities (responsible for the positive magnetic anomaly), which in turn indicate large variations in intrabasement rock type. If such features are superimposed on each other, it can be very difficult to separate; the effects of structures and susceptibility contrast (Gipson, 1998). Model cross-section (profile line 22) [Figure 13] show the prism-shaped bodies without in-fill colours displaying a horst-graben structure with the graben filled with Cretaceous sediment of $7000 \mathrm{~m}$. Recent work by Abbas and Mallam (2013) obtained sedimentary thickness of over 9000m in the Lower Benue Trough. The predominance of magnetic lows in the modelled residual field data indicate acidic basement (deformed granitic basement). Avbovbo (1980) using borehole data showed that the Benue Trough is underlain by Precambrian granitic continental crust.

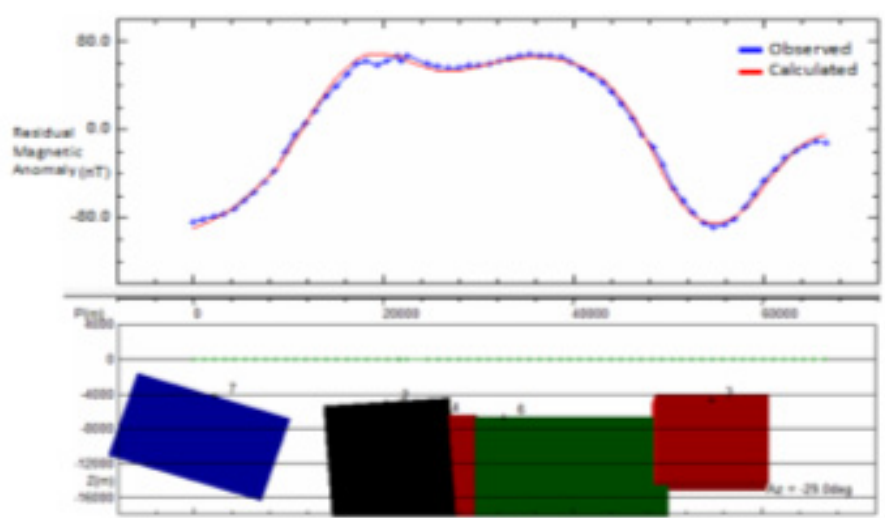

Figure 12. Modelling of residual magnetic anomaly along profile line 7 . The subsurface magnetic model shows the graben structure in Anambra basin. The graben is bounded by high angle faults due the movement of basement horst blocks

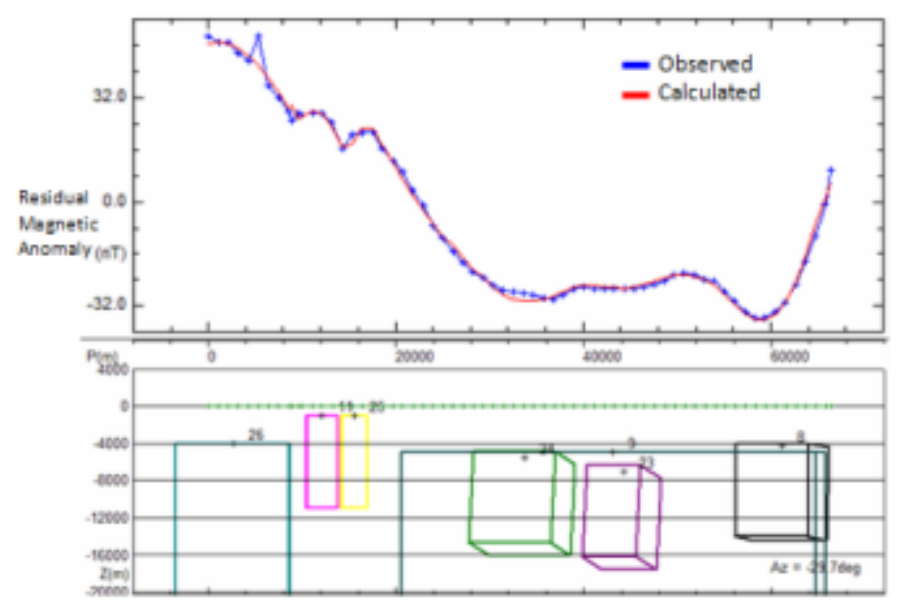

Figure 13. Modelling of residual magnetic field along profile line 22 shows the horst-graben structures in Nkalagu subbasin. The basement blocks are depicted with prism-shaped bodies without infill colours to highlight the basin architecture 


\subsection{Results from Qualitative Interpretation}

The results from qualitative interpretation presented in Figures 14-19 are based on the analyses of trends and linears in the gridded data sets. This involves identifying linear trends on the derivative and filtered maps that correspond to edges of structures, lithologic contacts and faults. It also involves partitioning of data into magnetic domains/subdomains. The magnetic transformation is a process of transforming observed magnetic anomaly field data into some new forms. The transformations, in general, do not directly define the distribution of sources but they often provide insights that help enhance a general understanding of the nature of sources with the naked eye (Li, 2009). The overall objective is to unravel subtle linear breaks in the potential field data. The analytic signal approach in Figure 14 is a contact mapping technique that reveals maxima. The most geologically significant anomalies on a given map are probably the more subtle ones and not necessarily the largest or most prominent anomalies (Breiner, 1973). The cessation/termination, displacement or interruption of otherwise long or continuous magnetic anomalies seen in Figures 14-17 represent significant geologic structural information and are pre-existing weakness in the crust typical of rift zone and deep seated faults that may have been reactivated by stress. The E-W trending lineaments in Figures $16 \& 17$ are interpreted as fault (sinistral strike-slip wrench) systems in the Lower Benue Trough. The steep gradients evident in the gradient maps are reflection of sharp discontinuities or interfaces between basement blocks of contrasting properties, such as fault, basement shear zones and intrusive contacts. These are linear features commonly representing lithological contacts, faults, fractures and dyke swarms (Lee \& Morris, 2013)

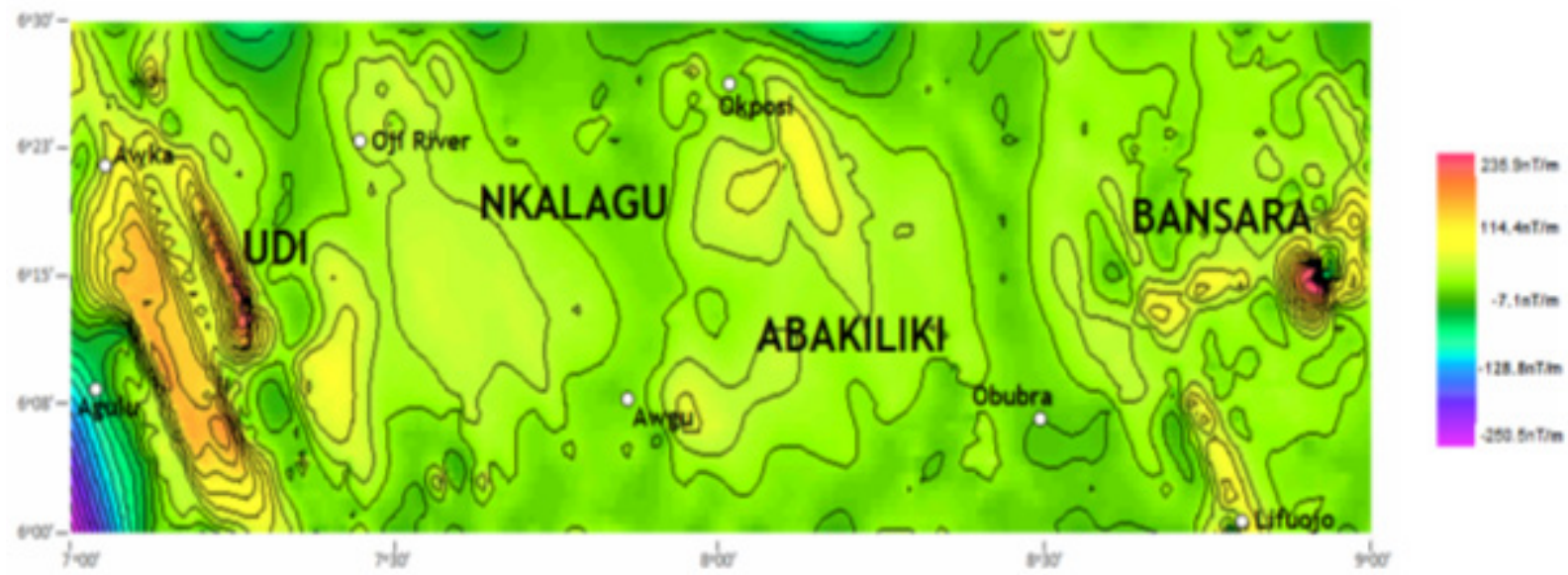

Figure 14. Analytic signal map showing maxima and minima. Areas with minima are interpreted as zones of depletion of magnetite

The faults in the gradient (dx) map (Figure 15) are specifically rift-stage faults associated with vertical rotation (tilting) of fault bounded blocks through which tectonic movement were transmitted. The alignment of discontinuous, multiple local anomalies in the map represent desirable faults. The analytic signal map (Figure 14) defines clearly the maxima of major magnetic anomalies and reveals also several subtle NNW-SSE trending magnetic lineaments that were not resolvable in the total intensity map. This result is significant because at low geomagnetic inclinations such as the Lower Benue Trough north-south structures would not produce anomaly if magnetization of the source is sorely due to induction in the earth's field. Thus, the interpretation of magnetic anomalies at low geomagnetic inclinations depends on the strike of the geologic features and the anomaly patterns they produce (Bird, Hall, Casey \& Millegan, 1998). Earlier studies on maximum amplitudes of analytic signal for location of structural boundaries show that the result is independent of the earth's magnetic field parameters and of the direction of magnetization (Nabighian, 1972, 1974; Roest, Verhoef \& Pilkington 1992; Hsu, Sibuet \& Shyu, 1996). This idea was regarded as an advantage in the interpretation of magnetic field data. However, our data showed the presence of anisotropic susceptibilities and remanent magnetization. These factors contributed in complicating the analysis of magnetic anomalies. If these factors are overlooked, structural inferences from magnetic data could be seriously in error. The Analytic signal amplitude also depends on burial depth extent, dipping angle of the source body, body's magnetization direction and earth's field direction ( $\mathrm{Li}$, 2006). The directional derivative (dx) map clearly defines the edges of magnetic anomalies and reveals some subtle N-S, NE and NW trending basement lineaments that correlate with magnetic boundaries. 


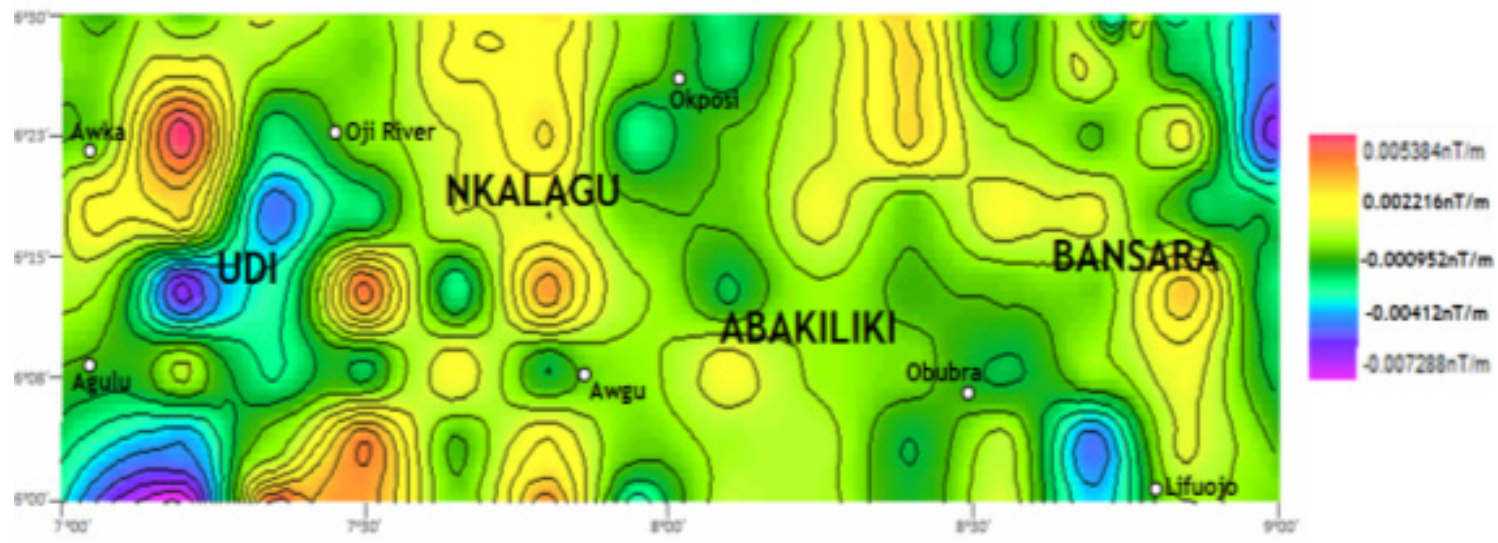

Figure 15. Directional derivative (dx) highlighting abrupt terminations of magnetic highs and lows which are characteristics of fault/fractures. The alignment of anomalies in N-S direction depicts high-angle rift-stage faults that contributed in the basin evolution

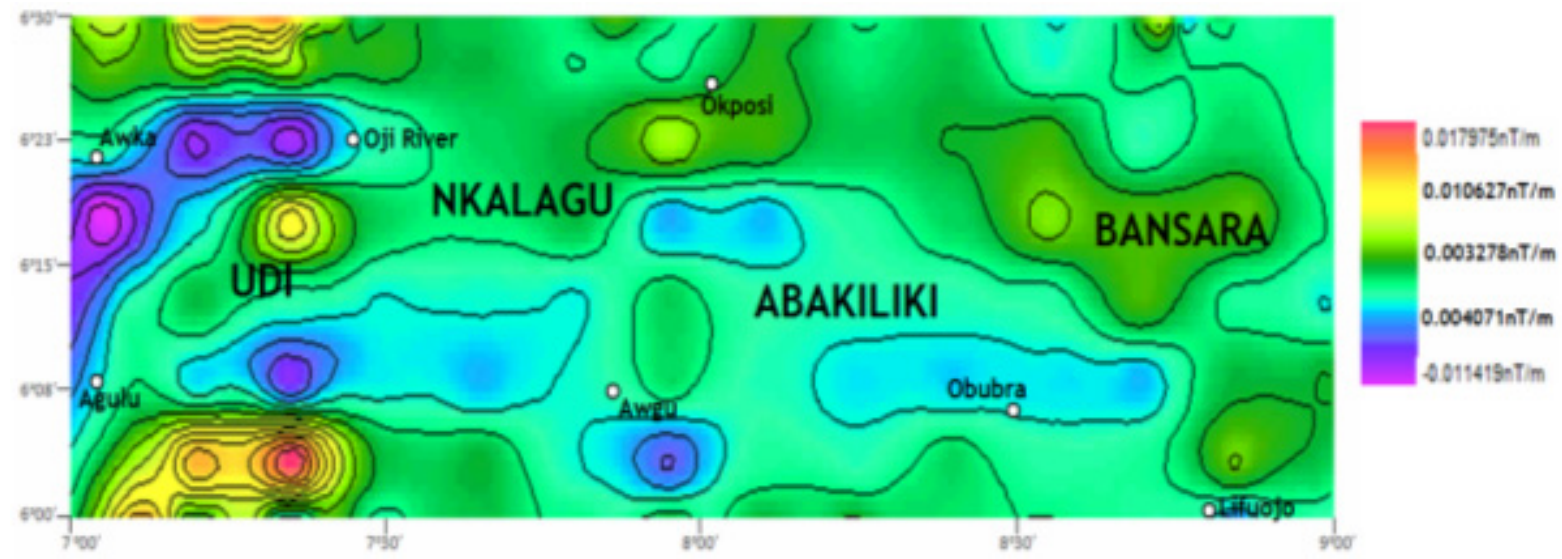

Figure 16. Predictably major E-W structural fabrics computed from the directional derivative (dy).Dislocation of the trend of anomalies and their alignment are signatures of fault/fractures

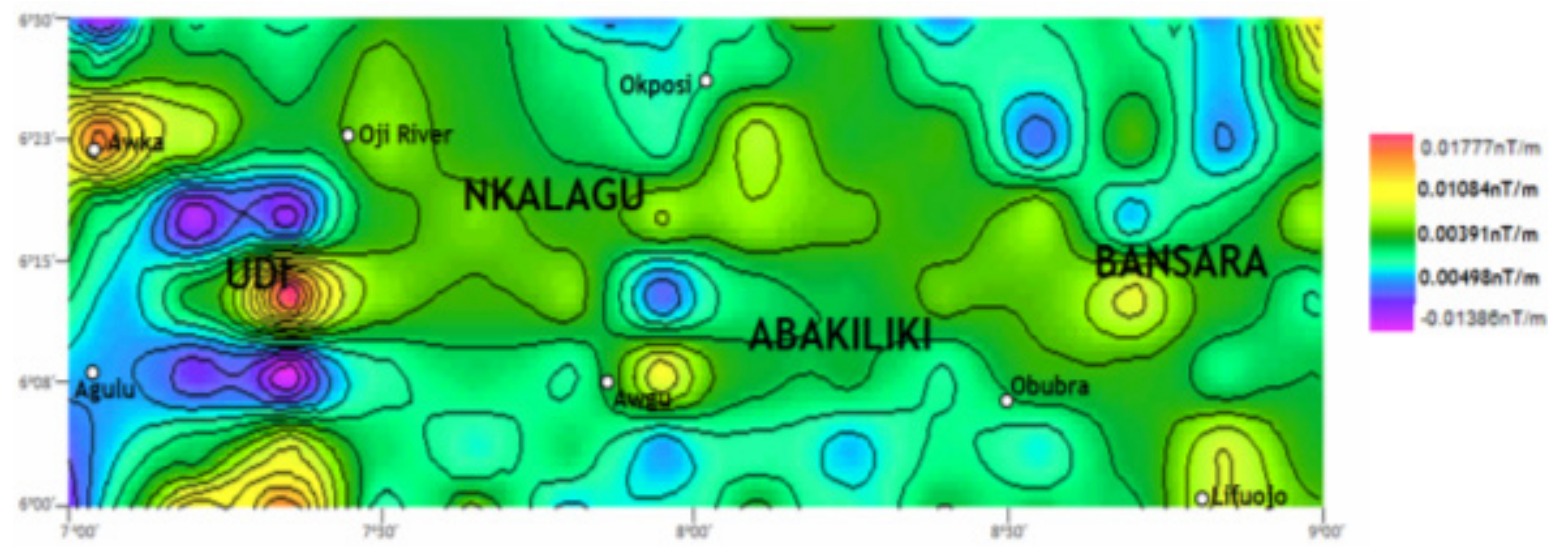

Figure 17. First vertical derivative (dz) map showing alignment of discontinuous multiple local anomalies which are desirable lineaments

Thus, magnetic anomaly maps can provide the template of deformation patterns and structural architecture in the basement that can be used to examine basement influence on sedimentary basin (Lee, Morris, Harris \& Leblanc, 2012). The anomalies in the gradient and filtered maps also show variability in lateral extent and amplitude and are pointers to spatial distribution of minibasins, half grabens and strike-slip-faulted fabrics. Structural fabric of 
the basement as shown in the gradient maps can therefore serve as an important tool for the prediction of the likely orientation of faults and fractures in the overlying Cretaceous sediments in the trough. These structures within the basement which influence the location of faulting within the sedimentary cover have been reported by Genik, 1992 and can also be visualized from the bounded fault block in the modelled cross-sections.

The circular and elongated magnetic highs predominant in the $\mathrm{dx}$ map (Figure 15) and dz map (Figure 17) are probably caused by deformed magnetite-bearing metamorphic basement and the predominant magnetic lows in dy map (Figure 16) are interpreted as zones of low magnetite content (deformed granitc plutons). Fairhead and Okereke (1987) using gravity data opined that the magnetic anomalies are caused by the topographic relief and the variable magnetic character of the metamorphosed basement beneath the Cretaceous trough. Well data by Avbovbo (1980) indicate that the basement rocks underlying Benue Trough are granitic with other acidic rocks, gneisses and migmatites. The filtered maps (Figure 18 \& Figure 19) show differential in geophysical domains.

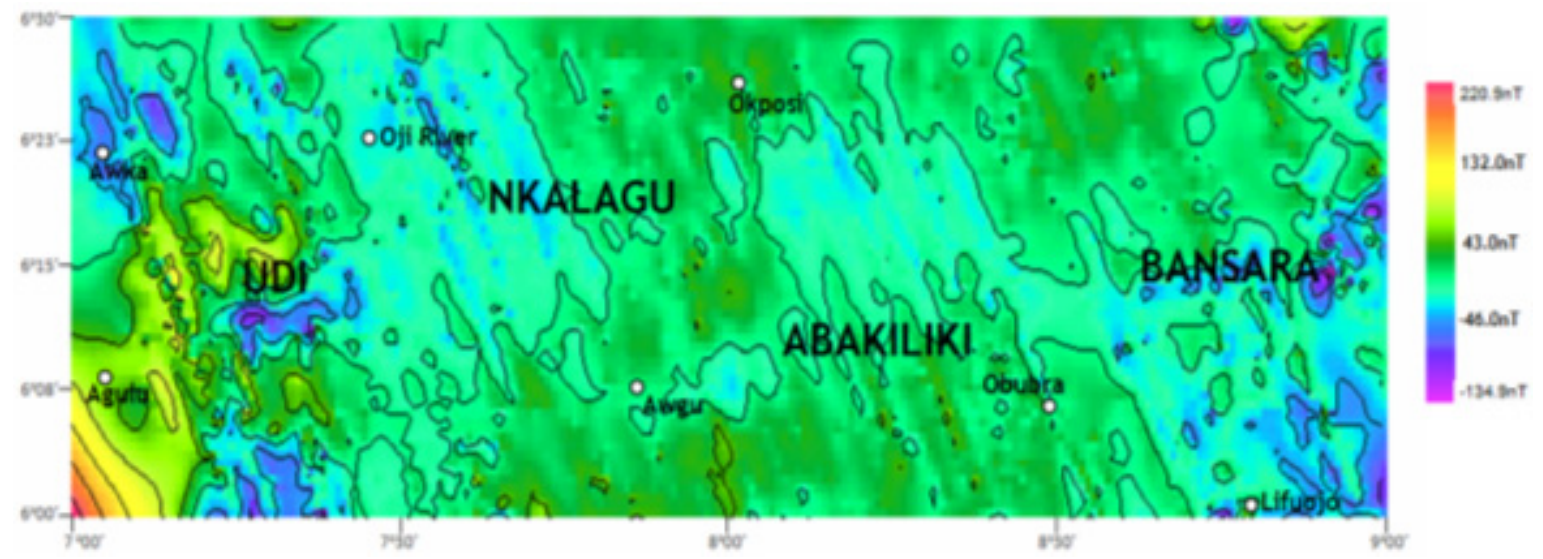

Figure 18. Low-pass filtered map of the Lower Benue Trough enhancing deeper crustal features

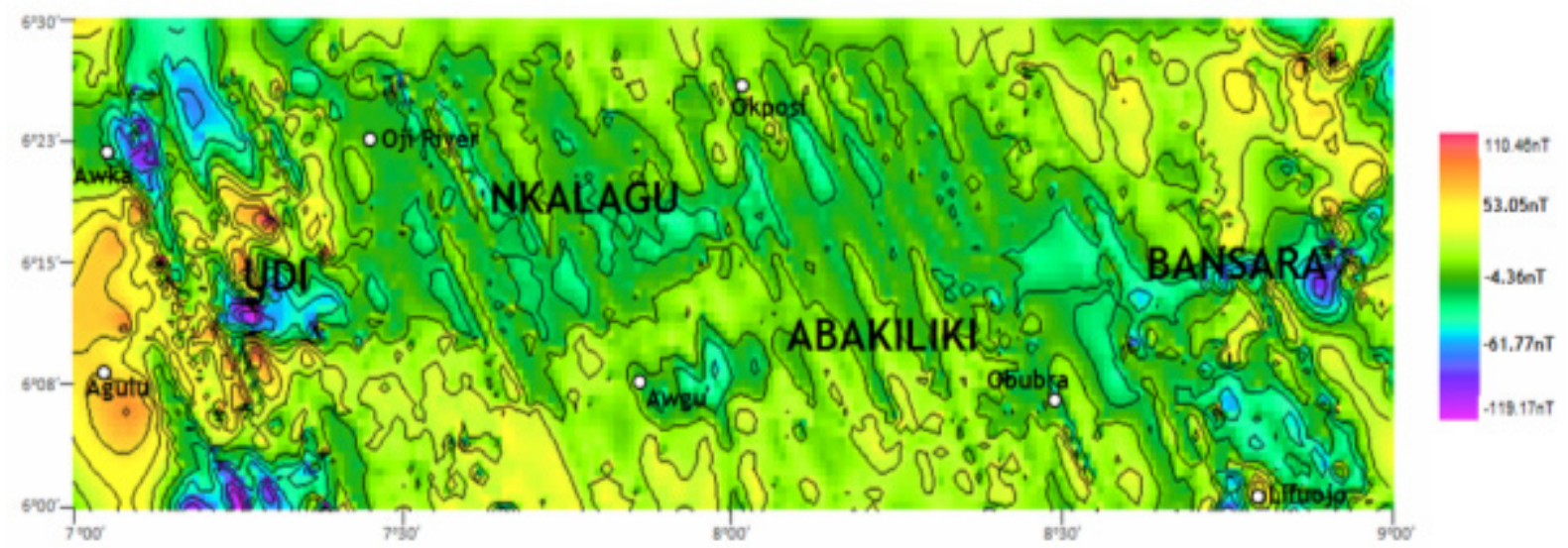

Figure 19. High-pass filtered map showing structural fabrics and upper crustal features of the Lower Benue Trough

Each domain is different by common characteristics of magnetic anomalies within it in terms of wavelength (e.g. relatively long wavelength anomalies in Figure18 as compared to shorter wavelength in Figure 19), dimensions and orientation (e.g. NNW-SSE structural fabric) and amplitude. These characteristics are related to the composition and deformation patterns of basement rocks and perhaps also to some secondary patterns of rock alteration or just basement depth (Lyatsky, Pana \& Grobe, 2005). The resultant filtered map (Figure 18) revealed the largest anomalies and the principal trend (NNW-NW) are more prominent. The principal trend constitute part of the regional configuration of the West and Central African rift system trending extensional basins taking up the strain caused by the NE to ENE oriented strike-slip motions emanating from the Gulf of Guinea (Eyike, Werner, Ebbing \& Dlournen, 2010; Fairhead, 1986; Fairhead and Okereke, 1987). 


\section{Discursion}

The basement fracturing, subsidence and rifting visualized from the transformed/enhanced magnetic data and subsurface magnetic models could be linked to the development of the Lower Benue during the Early Cretaceous opening of the South Atlantic Ocean. This active spreading from Albian to Santonian, a period of approximately 30m.y. has been established by combined evidence of marine sediments of Albian age, which extend into the Upper reaches of the Benue (Grant, 1971) and the probable limits in igneous/minerlization activity based on sparse radiometric data (snelling, 1965) and geological data (Cratechley \& Jones, 1965). This idea has also been supported by Akande etal., 1997. The spreading movement was terminated by appearance of strong Santonian folding of the sediments in the Southwestern part of the trough (Cratchley \& Jones, 1965) which constitute the Lower Benue Trough. The Santonian deformational event at $\sim 80 \mathrm{Ma}$ is widely spread in West and Central Africa as a short-lived period of compression producing folds parallel to the axis of the Benue Trough, Nigeria (Avbovbo etal., 1986). Except for minor rifting during the Senonian and Tertiary, the short-lived phase deformation marks the transition into the rift or "sag" phase of basin development. This deformational event can be correlated with a period of plate changes, recognized from fracture zone geometries seen in both the Central and South Atlantic Oceans (Binks \& Fairhead, 1992).

The depth to basement map (Figure 20) shows series of basement ridges, deep troughs and accommodation zones. The basement arches are important as a means of reconstructing the epeirogenic movements that have taken place in the trough. The arches serve as an important requirement for repeated fracture rejuvenation and the fault block rotation that may serve as hydrocarbon plays. The accommodation zones form basement highs and any influx of fluvial sediments can carry clastic material (e.g. sandstone) in the basin to the highs which may serve as hydrocarbon reservoir. The shear zones in the residual field maps and faults/fractures seen in the derivative maps are the main pathways systems through which all other basin fluids are known to have been transported in the geological past. Most of these still represent serious potential environmental hazards to basin storage-disposal practices, particularly in the light of any potential for changes in fluid migration pathways as direct result of contemporary fault activity (Sandford, Thompson \& Mcfalll, 1985). The basement arche in the vicinity of Abakiliki in the basement depth map constitute Senonian intrusive rocks which crop out from the Abakiliki anticlinorium into the Benue Trough. These rocks were permanently injected along fractures and should give clues to location of major fracture systems in the basement (Avbovbo, 1980). The minibasins in the depth to basement map suggests that sinistral wrenching is one of the major deformational processes responsible for the development of the Lower Benue Trough. The sinistral wrenching resulted in mean low anisotropic susceptibility $(\mathrm{kb})$ of basement rocks on the order of $-6.7 \times 10^{-4}$ SI. Result from model cross-section (line 15) [Figure 22] established from residual field map (Figure 21) adjacent to the study area shows the possibility of a depth to basement (sedimentary thickness) of over $9,000 \mathrm{~m}$. This thick sedimentation represent thermal sag which is a regional post-rift subsidence linked with rapid period of subsidence and sedimentation associated with the West and Central African systems.

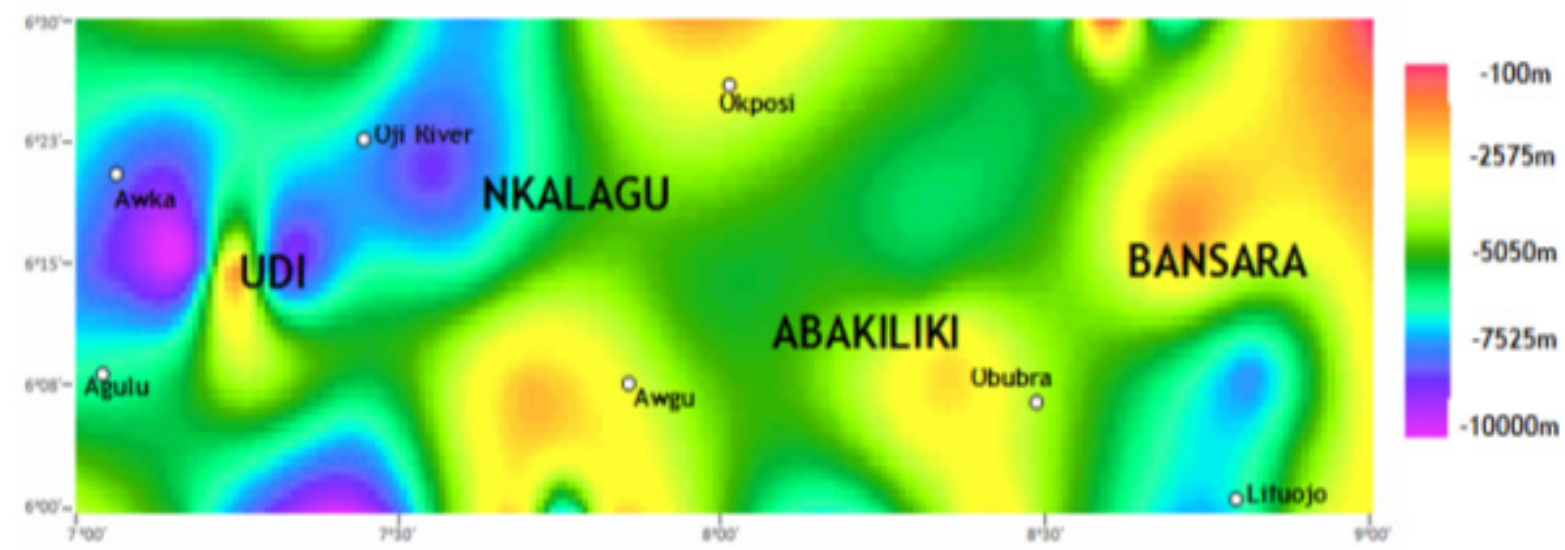

Figure 20. Minibasins segmented by basement ridges in the depth to basement map. The depocenters are at Abakiliki, Nkalagu, Awka and Oji River 


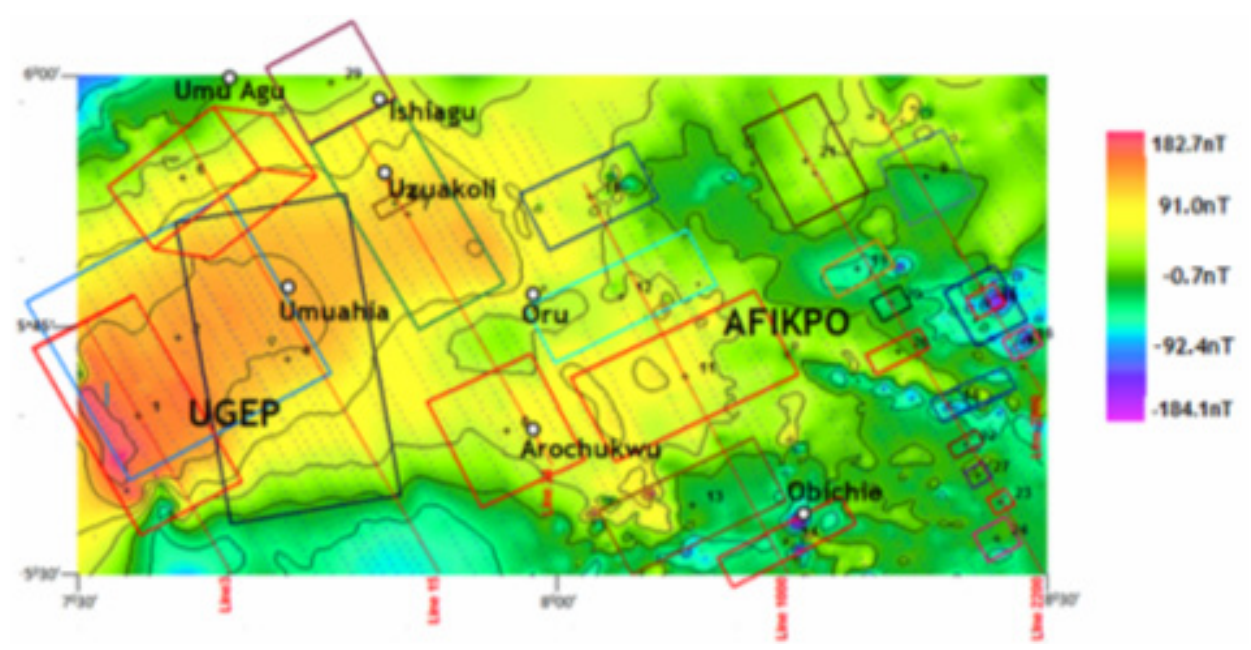

Figure 21. Residual magnetic field anomaly map adjacent to the main area of study

The model cross-sections that defined the rift structure of the Lower Benue Trough show that the crust thins to the north. This is an extensional tectonism that may have been activated by plate tectonic movement. The thinning of the crust resulting in extension and subsequent subsidence has been comprehensively presented by Okereke (1988) using gravity data. The gravity model indicated that its formation was probably the result of regional horizontal stresses in the lithosphere causing crustal extension and surface subsidence. The block faulting and the rift-structure interpreted from the magnetic models constitute the first stage in the development of the Lower Benue Trough and this agrees with the models of Mckenzie (1978). This model is proposed for the development and evolution of sedimentary basins of which the first event consists of a rapid stretching of continental lithosphere, which produces thinning and passive upwelling of hot asthenosphere. The lithosphere then thickens by heat conduction to the surface and further slow subsidence occurs which is not associated with faulting. From both geological and geophysical observations it is suggested that the rifted basins of West and Central Africa are among the best examples of the Mckenzie (1978) passive extensional basin model. The Early Cretaceous onset of basin formation in these areas was associated with rifting along the margins of the future South Atlantic (Binks \& Fairhead, 1992).

Minor magmatic activity took place in the Lower Benue Trough which can be demonstrated from the dyke-like (line of monopoles) structures and igneous plugs (point pole) that intruded the basin (Figures 23-24). A further reason for postulating a non-magmatic origin of the $50 \mathrm{~km}$ wide positive anomaly within the rift is the general lack of surface volcanism within the Benue compared to the East African rift system (Fairhead \& Okereke, 1987). The emplacement of the dykes in Figure 23 must have occurred during a period of crustal extension. Thus, the West African rift system contrasts sharply with the East African system which is associated with crustal doming, uplift of the rift margins and major magmatic activity (Fairhead, 1986).

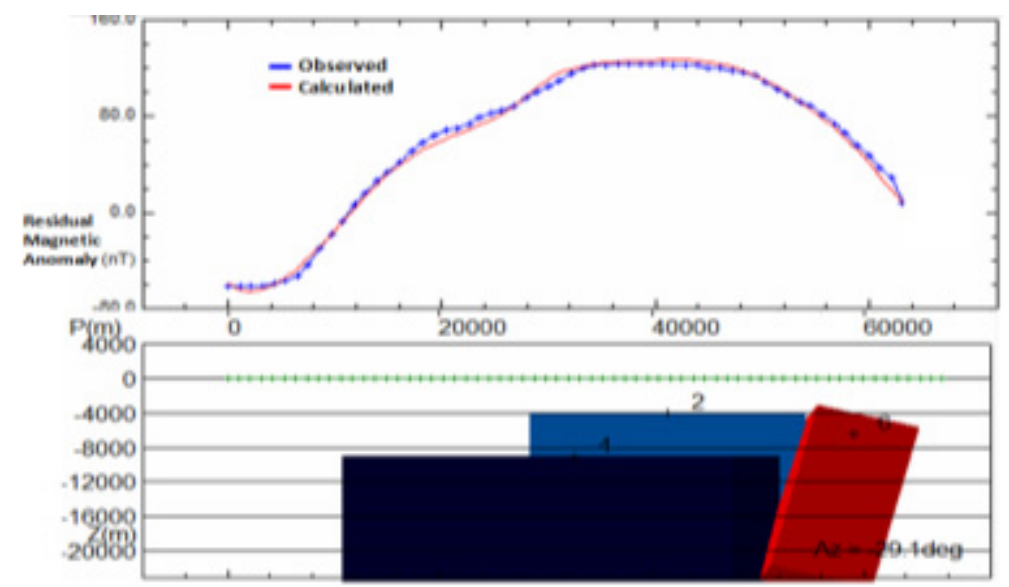

Figure 22. Magnetic anomaly of amplitude, 100nT from model cross-section in fig. 21, showing both lithological and structural variations. The depth to the top of the basement blocks indicate deep sedimentation (4000-9000m) in the trough 
Similar tectonic features such as graben, half graben and steep, high angle faults interpreted from the magnetic data have been reported by De Castro (2011) from the geophysical study of Potiguar Basin in Brazil, the counterpart of the Benue Trough. These structural features may serve as depocenters and conduits for hydrocarbon in the study area. The local magnetic minima predominant in the data set generated by lows in basement magnetization may be sites for hydrocarbon deposits as demonstrated by Piskarev \& Tchernyshev (1997) in hydrocarbon fields in northern west Siberia. They showed the relationship between slopes of positive magnetic anomalies and hydrocarbon deposits which is interpreted as relating to deep riftogenic structures. The magnetic susceptibility values resulting from the residual field modelling may be useful in locating hydrocarbon deposits in the study area as in the case of Barinas Apure basin, Venezuala, where high magnetic susceptibilities were observed to coincide to the top of the sedimentary units corresponding to reservoir and source rocks of oil-producing wells (Perez-Perez, D"onofrio, Bosch \& Zapata, 2011). This relationship between magnetic anomalies and hydrocarbon fields has also been established in cement oil field Oklahoma (Reynolds, Webring, Grauch \&Tuttle, 1990) and in the Niger delta basin (Okiwelu, Ofrey-Kulo \& Ude, 2013). Shelf sandstones members of the Cretaceous aged Asu River group and shallow marine Ezu Aku formations, as well as Nkporo and Ajali (Maastrichtian) [Figure 3] are proven petroleum reservoirs in the study area. For example, gas has been tested from sands of the Ezu Aku (Ihandiagu-1); Awgu (Ihandiagu-1, Amansiodo-1); the Nkporo (Alo-1, Ighariam-1) and Mamu (Alo-1), with minor oil in the Nkporo and Mamu (Maastrichtian sands interbedded with the coal measures) [Thomas (1996)].

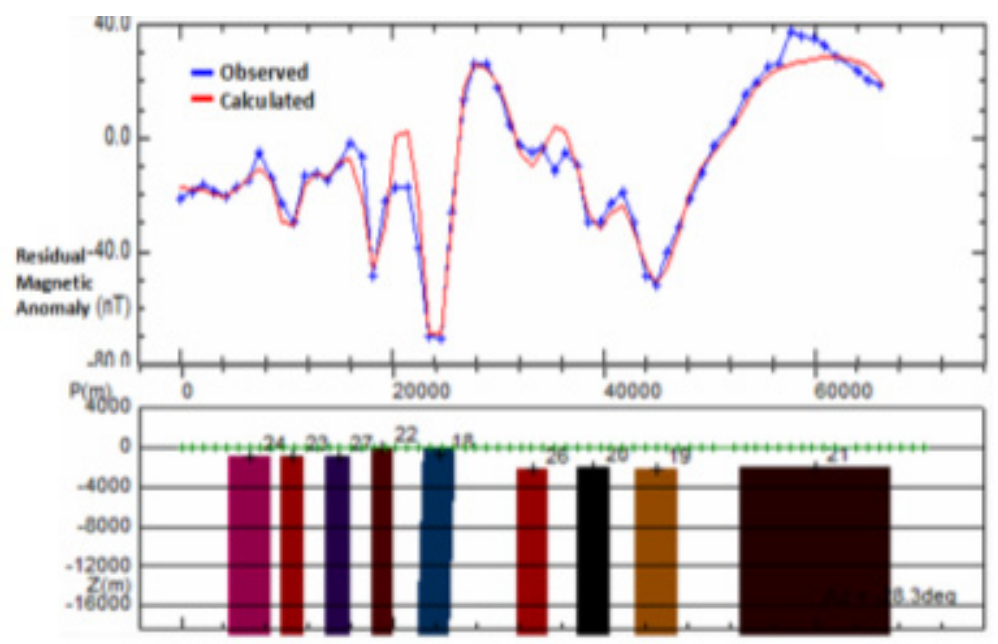

(a)

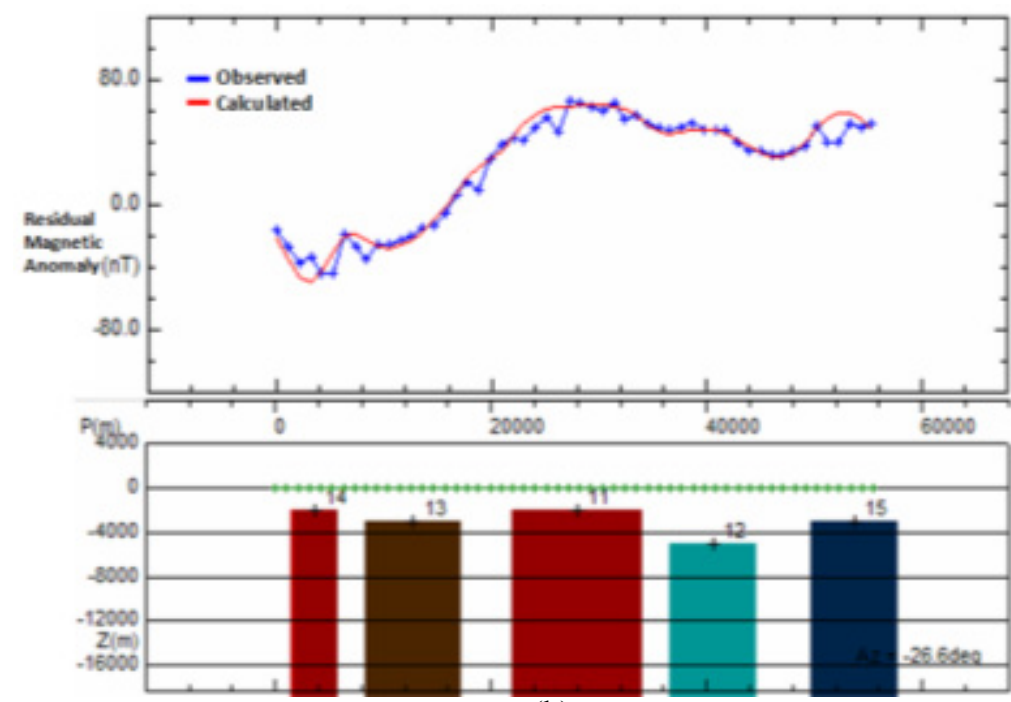

(b)

Fig. 23. Cross-section magnetic model through the study area (fig.21) obtained by simulating simple geometric forms using their equivalent geophysical models (a) line of monopoles (b) predominantly monopoles 


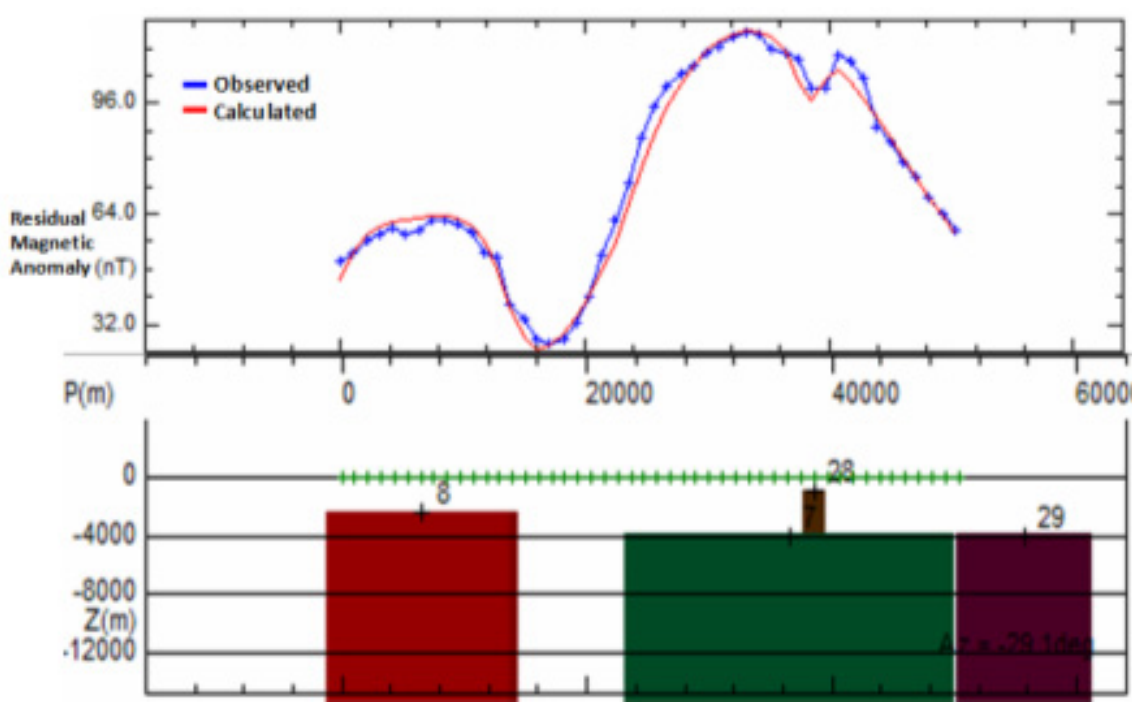

Figure 24. Model cross-section from Fihure 21 showing different geophysical models. The igneous plug (monopole) intruded into the basement block (sheet of dipole) and the sedimentary section

\section{Conclusion}

The results from the magnetic modeling revealed four sub-basins in the Lower Benue Trough with maximum thickness of $7-10 \mathrm{~km}$, indicating rapid periods of subsidence and thick sedimentation. The minibasins are interconnected by basement ridges (horsts). The high-angle rift-stage faults and the NW-SE, E-W, N-S trending fabrics controlled the internal geometry of the trough. The high-angle faults, lithological contacts and shear zones played major role in the rifting of the Lower Benue Trough. The anisotropic susceptibilities and remanence exhibited by the intrabasement sources are as a result of these deformational processes linked to the tectonic setting of the trough and rocks of granitic and metamorphic compositions. These physical parameters, geological evidences and general lack of surface volcanism within the Benue compared to the East African rift system indicate a non-magmatic origin of the trough. The crustal thickness obtained in this study agrees with previous geophysical (gravity) studies in the trough. The combined qualitative and quantitative interpretation gave an understanding of tectonic control on basin development and tectonic implication on basin architecture. The identified subtle structural fabrics are significant for hydrocarbon prospectivity in the trough.

\section{References}

Abbass, A. A., \& Mallam, A. (2013). Estimating the thickness of sedimentation within Lower Benue basin and Upper Anambra basin, Nigeria using both spectral depth determination and source parameter imaging. ISRN Geophysics, 2013, 1-10. http://dx.doi.org/10.1155/2013/124706

Adighije, C. I. (1981). Gravity study of Lower Benue Trough, Nigeria. Geological Magazine, 118(1), 59-67. http://dx.doi.org/10.1017/S0016756800024808

Ajakaiye, D. E., Hall, D. H., Millar, T. W., Verheijen, P. J. T, Awad, M. B., \& Ojo, S. I. (1986). Aeromagnetic anomalies and tectonic trends in around the Benue Trough, Nigeria. Nature, 319(13), 582-584. http://dx.doi.org/10.1038/319582a0

Ajayi, C. O., \& Ajakaiye, D. E. (1980). The origin and peculiarities of the Nigerian Benue Trough - another look from recent gravity data obtained from the Middle Benue. Tectonophysics, 80, 285-303. http://dx.doi.org/10.1016/0040-1951(81)90154-2

Akande, S. O., Abimbola, A. F., \& Erdtmann, B. D. (1997). Upper Cretaceous phosphorites in the Benue Trough of Nigeria: Distribution, properties and origin. Proc. Fourth Biennial SGA meeting. Heikki Papunen (ed.), 519-522.

Avbovbo, A. A. (1980). Basement geology in the sedimentary basins of Nigeria. Geology, 8, 323-327. http://dx.doi.org/10.1130/0091-7613(1980)8\%3C323:BGITSB\%3E2.0.CO;2

Avbovbo, A. A., Ayoola, E. O., \& Osahon, G. A. (1986). Depositional and structural styles in the Chad Basin of northeastern Nigeria. AAPG Bulletin, 70(12), 1787- 1789.

Benkhelil, J. (1982). Benue Trough and Benue chain. Geological Magazines, 119, 155-168. http://dx.doi.org/10.1017/S001675680002584X 
Benkhelil, J., \& Robineau, B (1983). Is the Benue Trough a rift? Bulletin of Central Research and Exploration Production. Elf-Aquitaine, 7, 315-321.

Bhattacharyya, B. K. (1964). Magnetic anomalies due to prism-shaped bodies with arbitrary polarization. Geophysics, 29(4), 517- 531. http://dx.doi.org/10.1190/1.1439386

Binks, R. M., \& Fairhead, J. D. (1992). A plate tectonic setting for Mesozoic rifts of West and Central Africa. Tectonophysics, 213, 141-151.http://dx.doi.org/10.1016/0040-1951(92)90255-5

Bird, D. E. (1997). Primer: Interpreting magnetic data. American Association of Petroleum Geologist Explorer, $8(5), 18-21$.

Bird, D. E., Hall, S. A., Casey, J. F., \& Millegan, P. S. (1998). Interpretation of magnetic anomalies at low latitudes: potential pitfalls. Geologic applications of Gravity and Magnetics: case Histories. In I. Gibson., \& P. S. Millegan. (Eds.), SEG Geophysical Reference No.8 and AAPG Studies in Geology (No. 43, pp. 53-57). Tulsa, United States.

Breiner, S. (1999). Application manual for portable magnetometers. California, Geometrics

Briggs, I. C. (1974). Machine contouring using minimum curvature. Geophysics, 39, 39-48. http://dx.doi.org/10.1190/1.1440410

Burke, K. C., Dessauvagie, T. F. J., \& Whiteman, A. J. (1970). Geological history of the Benue Valley and adjacent areas. In T. F. J. Dessauvagie, \& A. J. Whiteman (Eds.), African Geology (pp. 187-205), University of Ibadan, Ibadan.

Carter, J. D., Barber, W., \& Tait, E. A. (1963). The geology of parts of Adamawa, Bauchi and Bornu Provinces in northeastern Nigeria. Bulletin Geological Survey of Nigeria, 30, 109.

Cratchley, C. R., \& Jones, G. P. (1965). An interpretation of the geology and gravity anomalies of the Benue Valley, Nigeria. Geophysics Papers Overseas Geological Survey, 1, 26.

De Castro, D. L. (2011). Gravity and magnetic joint modeling of the Potiguar rift Basin (NE Brazil): Basement control during Neocomian extension and deformation. Journal of South American Earth Sciences, 31(2-3), 186-198.

Elawadi, E., Zaman, H., Batayneh, A., Mogren, S., Laboun, A., Ghrefat, H., \& Zumlot, T. (2013). Structural interpretation of the Ifal Basin in north-western Saudi Arabia from aeromagnetic data: hydrogeological and environmental implications. Exploration Geophysics, 44, 251- 263. http://dx.doi.org/10.1071/EG12069

Eyike, A., Werner, S. C., Ebbing, J., \& Dicoum, E. M. (2010). On the use of global potential field models for regional interpretation of the West and Central African Rift system. Tectonophysics, 492(1-2), 25-39. http://dx.doi.org/10.1016/j.tecto.2010.04.026

Fairhead, J. D. (1986). Geophysical controls on sedimentation within the African Rift Systems. In L.E. Frostick, R.W. Renaut, I. Reid, \& J. J. Tiercelin (Eds.), Sedimentation in the African Rifts. Geological Society Special Publication (Vol. 25, pp. 19-27).

Fairhead, J. D. (2012). Regional tectonics and basin formation: The role of potential field studies in Phanerozoic. Regional Geology of the world, 12, 330-341. htt://dx.doi.org/10.1016/B978-0-444-53042-4.00012-1

Fairhead, J. D., \& Okereke, C. S. (1987). A regional study of the West African Rift system in Nigeria and Cameroon and its tectonic interpretation. Tectonophysics, 143, 141-159. http://dx.doi.org/10.1144/GSL.SP.1986.025.01.03

Fitton, J. G. (1980). The Benue Trough and Cameroon line - A migrating rift system in West Africa. Earth Planet Science Letters., 51, 132-138. http://dx.doi.org/10.1016/0012-821X(80)90261-7

Freeth, S. J. (1982). Deep structure of the West African Rift system. EOS, 63, 1117.

Freeth, S. J. (1984). How many rifts are there in West Africa? Earth Planet Science Letters, 67, 219-227. http://dx.doi.org/10.1016/0012-821X(84)90117-1

Genik, G. J. (1992). Regional framework and structural aspects of of rift basins in Niger, Chad and the Central African Republic (C.A.R.). In P.A Ziegler (Editor), Geodynamics of Rifting, Volume II. Case History Studies on Rifts: North and South America and Africa. Tectonophysics, 213, 169-185. http://dx.doi.org/10.1016/0040-1951(92)90257-7

Gibson, R. I. (1998). Magnetic susceptibility contrast versus structure: Geologic applications of Gravity and Magnetics: case Histories. In I. Gibson., \& P. S. Millegan. (Eds.), SEG Geophysical Reference No.8 and 
AAPG Studies in Geology (No. 43, pp. 79-81). Tulsa, United States.

Grant, N. K. (1971). South Atlantic, Benue Trough and Gulf of Guinea Cretaceous Tripple junction. Geolological Society of American Bulletin, 82(8), 2395-2298.

Hsu, S., Sibuet, J., \& Shyu, C. (1996). High-resolution detection of geologic boundaries from potential-field anomalies: An enhanced analytic signal technique. Geophysics, 61(2), 373-386. http://dx.doi.org/10.1190/1.1443966

Igwesi, D. I., \& Umego, M. N. (2013). Interpretation of aeromagnetic anomalies over some parts of Lower Benue Trough using spectral analysis technique. International Journal of Scientific and technological research, 2(8), 153-165.

Lee, M., \& Morris, W. (2013). Quality assurance of aeromagnetic data using lineament analysis. Exploration Geophysics, 44, 104-113. http://dx.doi.org/10.1071/EG12034

Lee, M., Morris, W., Harris, J., \& Leblanc, G. (2012). A network extraction tool for mineral exploration: A case study from the Wopmay Origin, Northwest territories, Canada: Exploration Geophysics. Retrieved from http://www.publish.csiro.au/journals/eg

Li, X. (2006). Understanding 3D analytic signal amplitude. Geophysics, 71(2), 13-16. Retrieved from http://www.onepetro.org/mslib/servlet/onepetropreview?id=SEG-2009-0928.http://dx.doi.org/10.1190/1.218 4367

Li, X. (2009). Spatial-Domain Transformations: Something Old and Something New.

Lyatsky, H. V., Pana, D. I., \& Grobe, M. (2005). Basement structure in Central and Southern Alberta: Insights from Gravity and Magnetic maps, Alberta Energy and Utility Board/Alberta Gelogical Survey (EUB/AGS) special report 72, 83p.

Mckenzie, D. P. (1978). Some remarks on the development of sedimentary basins. Earth Planet Scienc Letters., 40, 25-32. http://dx.doi.org/10.1016/0012-821X(78)90071-7

Nabighian, M. N. (1972). The analytic signal of two-dimensional magnetic bodies with polygonal cross-section: Its properties and use for automated anomaly interpretation. Geophysics, 37, 507-517. http://dx.doi.org/10.1190/1.1440276

Nabighian, M. N. (1974). Additional comments on the analytic signal of two dimensional magnetic bodies with polygonal cross-section. Geophysics, 39, 85-92. http://dx.doi.org/10.1190/1.1440416

Obaje, N. G. (2009). Geology and mineral resources of Nigeria. In S., Brooklyn, H. S. N., Neugebauer, H. J., Bonn, J. R., \& Gottingen, K. S. (Eds.), lecture notes in Earth sciences. Bhattacharji. http://dx.doi.org/10.1007/978-3-540-92685-6

Ofoegbu, C. O., \& Onuoha, K. M. (1990). Analysis of magnetic data over the Abakiliki Anticlinorium of the Lower Benue Trough, Nigeria. Marine and Petroleum Geology, 8, 174-183. http://dx.doi.org/10.1016/0264-8172(91)90005-L

Okereke, C. S. (1988). Contrasting modes of rifting: The Benue and Cameroon volcanic line, West Africa. Tectonophysics, 7(4), 775-784. http://dx.doi.org/10.1029/TC007i004p00775

Okereke, C. S., Ofoegbu, C. O., \& Ezeanyim, V. I. (1990). Cretaceous sediment thickness in the Benue Tough, Nigeria, determined from gravity interpretation. Bullett. DI Geofisica Teorica ED Appl. XXXII. N. 127.128, 257-266.

Okiwelu, A. A., Ofrey-Kulo, O., \& Ude, I. A. (2013). Interpretation of regional magnetic rield data offshore Niger Delta reveals relationship between deep basement architecture and hydrocarbon target. Earth Science Research, 2(1), 13-32. http://dx.doi.org/10.5539/esr.v2n1p13

Olaniyan, O., Smith, R. S., \& Morris, B. (2013). Qaulitative geophysical interpretation of the Sudbury structure. Interpretation, 1(1), 25-43.

Oyedim, G. C., Alagoa, K. D., Adedokun, I. O., Aderogb, A. A., \& Ovuru, C. C. (2009). Mapping high-angle basement faults in the middle Benue Trough, Nigeria from gravity inversion surface. Earth science research Journal, 13(2), 140-147.

Perez-Perez, A., D’onofrio, L., Bosch, M., \& Zapata, E. (2011). Association between magnetic susceptibilities and hydrocarbon deposits in the Barinas-Apure basin, Venezuela. Geophysics, 76(6), 35-41. http://dx.doi.org/10.1190/geo2010-0274.1 
Petters, S. W. (1978). Stratigraphic evolution of the Benue Trough and its implications for the Upper Cretaceous paleogeography of West Africa. Journal of Geology, 86, 311-322. http://dx.doi.org/10.1086/649693

Piskarev, A. L., \& Tchernyshev, M. Y. (1997). Magnetic and gravity anomaly patterns related to hydrocarbon fields in northern West Siberia. Geophysics, 62(3), 831-841. http://dx.doi.org/10.1190/1.1444192

Reynolds, R. L., Webring, M., Grauch, V. J. S., \& Tuttle, M. (1990). Magnetsic forward models of cement oil field, Oklahoma, based on rock magnetic, geochemical and petrologic constraints. Geophysics, 55(3), 344-353. http://dx.doi.org/10.1190/1.1442842

Roest, W. R., Verhoef J., \& Pilkington M. (1992). Magnetic interpretation using the 3-D analytic signal. Geophysics, 57, 116-125. http://dx.doi.org/10.1190/1.1443174

Sanford, B. V., Thompson, F. T., \& Mcfall, G. H. (1985). Plate tectonics - Possible controlling mechanism in the development of hydrocarbon traps in Southwestern Ontario. Bulletin of Canadian Petroleum Geology, 35(1), 57-71.

Shemang Jr., E. M., Ajayi, C. O., \& Umego, M. N. (1998). The structure of the Gongola Arm of the Upper Benue Trough as revealed by gravity and magnetic studies. Nigerian Association of Petroleum Explorationist, 13(1), 50-69.

Snelling, N. J. (1965). Age determination unit, in Annual Report Institute Geological Sciences for 1964, 35p.

Thomas, D. (1996). Benue and Mid-African rift system: oil and gas exploration (Nigeria, part 5). Retrieved from $\mathrm{http} / / /$ www.ogj.com/...5/.../exploration/nigeria-5-benue-trough-and-the-mid-af

Wright, J. B. (1968). South Atlantic continental drift and the Benue trough. Tectonophysics, 6, 301-310. http://dx.doi.org/10.1016/0040-1951(68)90046-2

\section{Copyrights}

Copyright for this article is retained by the author(s), with first publication rights granted to the journal.

This is an open-access article distributed under the terms and conditions of the Creative Commons Attribution license (http://creativecommons.org/licenses/by/3.0/). 